\title{
Selenium Modulates Growth and Thiol Metabolism in Wheat (Triticum aestivum L.) during Arsenic Stress
}

\author{
Srijita Ghosh, Asok K. Biswas* \\ Plant Physiology and Biochemistry Laboratory, Centre of Advanced Study, Department of Botany, University of Calcutta, \\ Kolkata, India \\ Email: *asokbiswas2016@yahoo.com
}

How to cite this paper: Ghosh, S. and Biswas, A.K. (2017) Selenium Modulates Growth and Thiol Metabolism in Wheat (Triticum aestivum L.) during Arsenic Stress. American Journal of Plant Sciences, 8, 363-389. https://doi.org/10.4236/ajps.2017.83026

Received: December 26, 2016

Accepted: February 3, 2017

Published: February 6, 2017

Copyright (@) 2017 by authors and Scientific Research Publishing Inc. This work is licensed under the Creative Commons Attribution International License (CC BY 4.0).

http://creativecommons.org/licenses/by/4.0/ (c) (i) Open Access

\begin{abstract}
Arsenic affects plants by disrupting their growth and metabolism while selenium, an essential micronutrient has beneficial role in stress tolerance. Owing to the antioxidative capacity of selenium, it can counteract detrimental effects of arsenic induced stress in plants. The interactive influence of arsenate and selenate on the growth, arsenic and selenium accumulation, activities of nonenzymatic and enzymatic antioxidants, levels of ascorbate, $\alpha$-tocopherol, total glutathione and activities of glutathione regulatory enzymes along with characterization and quantification of phytochelatins in growing wheat (Triticum aestivum L.) seedlings were investigated. Rate of arsenic accumulation was increased in arsenate treated seedlings while in seedlings treated jointly with arsenate and selenate, arsenic accumulation decreased. Arsenate stress resulted decrease in ascorbate and total glutathione contents, activities of the glutathione metabolism enzymes while significantly increased the levels of $\alpha$-tocopherol and phytochelatins (PC2 and PC4), along with activities of ascorbate peroxidase and ascorbic acid oxidase in the test seedlings. The effects were more pronounced in roots than in shoots. Joint application of arsenate along with selenate was able to overcome the adverse effects caused by arsenic alone to variable extents by exhibiting significant alterations of all parameters tested, imparting better growth and thiol metabolism in the test seedlings. Our results conclude that application of selenium fertilizer in arsenic contaminated soil might be favourable to improve growth and defense ability in wheat against arsenic toxicity.
\end{abstract}

\section{Keywords}

Arsenate, Glutathione, Phytochelatins, ROS, Selenate 


\section{Introduction}

Arsenic is found naturally in soils. The most common source of arsenic contamination is ground water, where concentrations range between $0.01 \mathrm{mg} \cdot \mathrm{l}^{-1}$ to 4 $\mathrm{mg} \cdot \mathrm{l}^{-1}[1]$. Arsenic in soil exists in two biologically important states-arsenate (V) and arsenite (III). Arsenite, biologically the more active and toxic form [2] is the major source to arsenic toxicity readily reacting with the sulfhydryl groups of proteins and inhibiting biochemical pathways, while arsenate, the dominant form available to plants in well aerated soil, acts as a phosphate analogue and interferes with phosphorylation reactions [3].

Arsenic adversely affects the growth and development of plants resulting in various biochemical and physiological disorders. Morphologically excess arsenic causes stunted growth, leaf chlorosis and necrosis, reduction in leaf area and photosynthetic activities. At the cellular level, arsenic induces oxidative stress, evidenced by enhanced lipid peroxidation, $\mathrm{H}_{2} \mathrm{O}_{2}$ production and ion leakage [4]. Arsenic is easily taken up by roots and transported to other parts of the plant, being toxic to living cells at very low concentrations. These features make arsenic a serious problem as the As-enriched plants can be transferred to the food chain. Presence of arsenic in irrigation water effects plant metabolism and leads to various physiological and structural disorders. Photosynthetic apparatus, cell division machinery, energy production and redox states are major section of plants that are badly affected by arsenic [5]. It also decreases root-shoot growth, and causes wilting and necrosis of leaf blade.

Selenium (Se) displays metalloid characteristics and occurs in different oxidation states like selenide, elemental selenium, selenite and selenate. Although not classified as a micronutrient for higher plants, Se exerts a beneficial effect on growth and stress tolerance of the plants by enhancing their antioxidative capacity. At lower concentration, Se can protect plants against the damage induced by heavy metals. Se levels lower than $1 \mathrm{mg} \cdot \mathrm{kg}^{-1}$ in the soil can enhance the plant growth because Se acts as antioxidant to decrease lipid peroxidation and increase GPx activity [6]. Low concentration of selenate below $20 \mu \mathrm{M}$ may be beneficial to the overall growth and metabolism in wheat seedlings [4].

Due to the similar physical and chemical properties (i.e., similar valence shells, electronic structures, and atomic radii), As and Se compounds can be biologically antagonistic to each other [7]. Owing to the antioxidant role of Se, it is hypothesized that Se can counteract the detrimental effects of As stress in plants [8]. It has been shown that Se addition reduced As uptake as well as its translocation from roots to fronds in Chinese Brake fern (Pteris vittata) [9], in wheat [4] and in rice [10] [11].

Glutathione (GSH) is an antioxidant that prevents damage to important cellular components caused by ROS during arsenic stress. Glutathione exists in both reduced (GSH) and oxidized (GSSG) form. An increased GSSG/GSH ratio is considered indicative of oxidative stress [12] [13]. In the reduced state of glutathione, the thiol group of cysteine is able to donate a reducing equivalent $\left(\mathrm{H}^{+}+\right.$ $\left.\mathrm{e}^{-}\right)$to other unstable molecules, such as ROS. In donating an electron, gluta- 
thione itself becomes reactive, but readily reacts with another reactive glutathione to form glutathione disulfide (GSSG). Such a reaction is probable due to the relatively high concentration of glutathione in cells produced in response to stress. GSH can be regenerated from GSSG by the activity of GR or GPx.

Phytochelatins (PCs) are a family of small, cysteine rich polypeptides produced in all higher plants under metal stress condition. They are synthesized from GSH through the actions of the PC synthase [14]. The polypeptides have the general structure ( $\gamma$-Glu-Cys)n-Gly, in which $n=2-11$ and PC2, PC3 are the most common [15]. PCs, possess a high antioxidant capacity and are thought to be the most important mechanism of detoxification in plants subject to metal stress, and are involved in the accumulation, chelation, sequestration and metabolism of metal ions [16]. Reports on As toxicity in plants show a clear role for PCs in the detoxification of As [17] [18].

Wheat is a leading source of vegetable protein in human food. In arsenic prone areas, farmers use arsenic contaminated groundwater for wheat cultivation causing direct harm to human health. In the present work, we investigated the potential role of Se application in modulating As induced oxidative stress and thiol metabolism in wheat. This would help in providing a basis for developing strategies to reduce risks associated with toxicity in arsenic contaminated soil.

\section{Materials and Methods}

\subsection{Plant Material and Arsenate Treatments}

Wheat (Triticum aestivum L. cv. PBW-343) seeds obtained from State Agricultural Research Station, Burdwan, West Bengal, were surface sterilized with sodium hypochlorite $(5 \% \mathrm{v} / \mathrm{v})$, followed by repeated washing in sterilized distilled water. About 50 seeds for each treatment were spread over in autoclaved petridishes $(\Phi 10 \mathrm{~cm})$ lined with filter papers. The seeds were kept in dark and humid conditions for 48 hours in a germinator at $25^{\circ} \mathrm{C} \pm 2{ }^{\circ} \mathrm{C}$. The germinating seeds were exposed to $20,50,100 \mu \mathrm{M}$ concentrations of sodium arsenate $\left(\mathrm{Na}_{2} \mathrm{HAsO}_{4} \cdot 7 \mathrm{H}_{2} \mathrm{O}\right.$; Loba-Chemie, India) solutions (w/v) with or without $10 \mu \mathrm{M}$ concentration of sodium selenate $\left(\mathrm{Na}_{2} \mathrm{SeO}_{4}\right.$ : Loba-Chemie, India) solution (w/v) and exposed to 16 hour photoperiod $\left(260 \mu \mathrm{mol} \cdot \mathrm{m}^{-2} \cdot \mathrm{s}^{-1} \mathrm{PFD}\right)$ for 19 days in presence of modified Hoagland solution, $\mathrm{pH} 7.2$ (containing $\mathrm{KH}_{2} \mathrm{PO}_{4}, \mathrm{KNO}_{3}, \mathrm{Ca}\left(\mathrm{NO}_{3}\right)_{2}, \mathrm{MgSO}_{4}, \mathrm{H}_{3} \mathrm{BO}_{3}$, $\mathrm{MnCl}_{2} \cdot 4 \mathrm{H}_{2} \mathrm{O}, \mathrm{ZnSO}_{4} \cdot 7 \mathrm{H}_{2} \mathrm{O}, \mathrm{CuSO}_{4} \cdot 5 \mathrm{H}_{2} \mathrm{O}, \mathrm{H}_{2} \mathrm{MoO}_{4} \cdot \mathrm{H}_{2} \mathrm{O}$ ) [19]. $10 \mu \mathrm{M}$ concentration of selenate was selected out of various concentrations tested along with arsenate to overcome inhibition of growth and metabolism induced by arsenic. The seedlings were harvested after 21 days for the following studies.

\subsection{Growth and Biomass Measurements}

The root and shoot lengths of arsenic and selenium treated wheat seedlings were measured after 21 days. From each treatment, 10 seedlings were harvested and weighed. The seedlings were allowed to dry at $70^{\circ} \mathrm{C}$ for 4 days and then at $100^{\circ} \mathrm{C}$ for 3 days. After the stipulated period, dry weights of the samples were taken and 
to determine water contents, the differences between fresh weight and dry weight of the seedlings were recorded [20].

\subsection{Estimation of Arsenic and Selenium Contents}

Total arsenic and selenium contents were measured from arsenic treated root and shoot of test seedlings after 21 days of growth by acid digestion of oven dried samples. The dried samples were digested in a Microwave Digestor using 7 $\mathrm{ml} \mathrm{HNO}{ }_{3}(65 \%), 5 \mathrm{ml} \mathrm{HCl}$ and $2 \mathrm{ml} \mathrm{H}_{2} \mathrm{O}_{2}$ for 60 minutes [21]. Arsenic and selenium concentrations of the samples were determined by Atomic absorption spectrophotometer (ICP-AES) Model No.6300 DUO (Thermofischer) with flow injection hydride generation system, using a standard curve prepared from known concentrations of arsenic and selenium. The arsenic and selenium contents were expressed in terms of $\mathrm{mg} \cdot \mathrm{kg}^{-1} \mathrm{DW}$.

\subsection{Assay of Ascorbic acid oxidase (AOX; EC 1.10.3.3) Activity}

AOX activity was assayed according to the method of [22]. $1 \mathrm{~g}$ sample was homogenized in $5.0 \mathrm{ml} 0.1 \mathrm{M}$ sodium phosphate buffer ( $\mathrm{pH} 7.0$ ), centrifuged at $12,000 \mathrm{~g}$ for 20 minutes and supernatant was used to assay the enzyme activity. Reaction mixture consisted of $3 \mathrm{ml}$ of $0.1 \mathrm{M}$ sodium phosphate buffer ( $\mathrm{pH} 7.0$ ), 1 $\mathrm{ml}$ of $0.025 \%$ ascorbic acid (w/v) and $1 \mathrm{ml}$ enzyme extract. After 30 minutes of incubation the reaction was stopped by adding $5 \mathrm{ml}$ of $10 \% \mathrm{TCA}(\mathrm{w} / \mathrm{v})$ and titrated with $0.02 \mathrm{M}$ DCPIP solution. The difference between the blank and sample OD determined the AOX activity and expressed as mg ascorbic acid decomposed $\mathrm{mg}^{-1}$ protein $\mathrm{min}^{-1}$.

\subsection{Assay of Ascorbate peroxidase (APX; EC 1.11.1.11) Activity}

$1 \mathrm{~g}$ sample was homogenized in $5.0 \mathrm{ml} 0.1 \mathrm{M}$ sodium phosphate buffer ( $\mathrm{pH} 7.0)$ containing $10 \% \mathrm{PVP}$, centrifuged at $12,000 \mathrm{~g}$ for 20 minutes and supernatant was used to assay the enzyme activity. Reaction mixture consisted of $0.1 \mathrm{M}$ sodium phosphate buffer ( $\mathrm{pH} 7.0$ ), $0.5 \mathrm{mM}$ ascorbic acid, $0.1 \mathrm{mM} \mathrm{H}_{2} \mathrm{O}_{2}, 0.1 \mathrm{mM}$ EDTA, and enzyme extract in a final volume of $700 \mu$. The change in absorbance at $290 \mathrm{~nm}$ was recorded after 1 minute. APX activity was calculated using extinction coefficient of $2.8 \mathrm{mM}^{-1} \cdot \mathrm{cm}^{-1}$ for ascorbate oxidized at $290 \mathrm{~nm}$ and expressed as $\mathrm{mg}$ ascorbic acid decomposed $\mathrm{mg}^{-1}$ protein $\mathrm{min}^{-1}$ [23].

\subsection{Estimation of Ascorbate Content}

$1 \mathrm{~g}$ sample was homogenized in $6.0 \mathrm{ml}$ ice-cold $6 \%$ TCA and homogenates was centrifuged at $11,500 \mathrm{~g}$ for 15 minutes at $4^{\circ} \mathrm{C}$. Ascorbate contents were determined according to [24] with modifications. Reaction mixture consisted of $4 \mathrm{ml}$

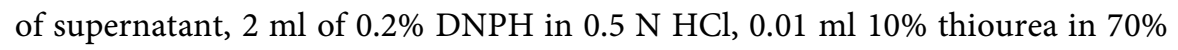
ethanol. The mixture was kept in boiling water bath for 15 minutes, cooled and 5 $\mathrm{ml}$ concentrated $\mathrm{H}_{2} \mathrm{SO}_{4}$ was added. Absorbance of the mixture was recorded at $530 \mathrm{~nm}$. A standard curve was prepared using known concentrations of ascorbic acid. Ascorbate contents were expressed as $\mu \mathrm{g}$ ascorbate $\mathrm{g}^{-1} \mathrm{FW}$. 


\subsection{Estimation of $\alpha$-Tocopherol Content}

The $\alpha$-tocopherol contents of the samples were assayed according to [25]. $1 \mathrm{~g}$ tissue was chopped and placed in $20 \mathrm{ml} 0.1 \mathrm{~N} \mathrm{H}_{2} \mathrm{SO}_{4}$, kept overnight and filtered. A mixture of $1.5 \mathrm{ml}$ supernatant and $1.5 \mathrm{ml}$ ethanol was centrifuged at $5000 \mathrm{~g}$ for 5 minutes at $4^{\circ} \mathrm{C}$ to mix thoroughly. In the mixture $1.5 \mathrm{ml}$ xylene was added and vortexed. In upper xylene fraction containing tocopherol, $1 \mathrm{ml}$ 2,2-dipyridyl reagent (Merck) was added. The absorbance of the mixture was recorded at 460 $\mathrm{nm}$. Then $0.33 \mathrm{ml} \mathrm{FeCl}_{3}$ was added to each tube and incubated for 15 minutes to develop colour and absorbance was recorded at $520 \mathrm{~nm}$. A standard curve was prepared using DL- $\alpha$ tocopherol and amount of tocopherol present in the sample was expressed as $\mu \mathrm{g}$ tocopherol $\mathrm{g}^{-1} \mathrm{FW}$.

\subsection{Estimation of Total Glutathione (GSH) Content}

Total glutathione contents were measured according to [26]. Samples were extracted in $5 \%(\mathrm{w} / \mathrm{v})$ sulphosalicyclic acid (SSA) containing $10 \mathrm{mM}$ EDTA and centrifuged at $10,000 \mathrm{~g}$ for 20 minutes at $4^{\circ} \mathrm{C}$. Total thiol contents were measured from the reaction mixture containing $100 \mathrm{mM}$ potassium phosphate buffer $(\mathrm{pH}$ 7.5), $1 \mathrm{mM}$ EDTA, $6 \mathrm{U} \cdot \mathrm{ml}^{-1}$ glutathione reductase (GR), $10 \mathrm{mM} \mathrm{DTNB}$ and 0.16 $\mathrm{mg} \cdot \mathrm{ml}^{-1} \mathrm{NADPH}$ and absorbance was recorded at $412 \mathrm{~nm}$ using Hitachi U-2000 spectrophotometer. The quantity of thiol was calculated as $\mu \mathrm{mol} \mathrm{GSH} \mathrm{g} \mathrm{g}^{-1} \mathrm{FW}$.

\subsection{Assay of Glutathione reductase (GR; EC.1.6.4.2) Activity}

$1 \mathrm{~g}$ test sample was extracted in $3 \mathrm{ml} 100 \mathrm{mM}$ potassium phosphate buffer $(\mathrm{pH}$ 7.5) containing $0.5 \mathrm{mM}$ EDTA, centrifuged at $15,000 \mathrm{~g}$ for 20 minutes at $4^{\circ} \mathrm{C}$ and supernatants was collected [27]. The assay mixture contained $100 \mathrm{mM}$ potassium phosphate buffer ( $\mathrm{pH}$ 7.5), $0.5 \mathrm{mM}$ EDTA, $0.75 \mathrm{mM}$ DTNB, $0.1 \mathrm{mM}$ $\mathrm{NADPH}$ and $1 \mathrm{mM}$ GSSG. The mixture was incubated at $35^{\circ} \mathrm{C}$ and absorbance was measured at $412 \mathrm{~nm}$ up to 5 minutes and the activity was calculated using the extinction coefficient of $6.22 \mathrm{mM}^{-1} \cdot \mathrm{cm}^{-1}$. GR activity was calculated as nmol of thiobis-2-nitrobenzoic acid formed $\mathrm{min}^{-1} \cdot \mathrm{mg}^{-1}$ protein and the activity was expressed as $\mathrm{nmol} \mathrm{min}^{-1} \cdot \mathrm{mg}^{-1}$ protein.

\subsection{Assay of Glutathione peroxidase (GPx; EC 1.11.1.9) Activity}

GPx activity was measured according to [28]. $1 \mathrm{~g}$ sample from each treatment was extracted in $220 \mathrm{mM}$ Tris- $\mathrm{HCl}$ (pH 7.4) containing $250 \mathrm{mM}$ sucrose, $50 \mathrm{mM}$ $\mathrm{KCl}, 1 \mathrm{mM} \mathrm{MgCl} 2,160 \mathrm{mM} \beta$-mercaptoethanol and $0.57 \mathrm{mM}$ PMSF. GPx activity was assayed in $20 \mathrm{mM}$ sodium acetate buffer ( $\mathrm{pH}$ 5.0) containing $30 \mathrm{mM}$ $\mathrm{H}_{2} \mathrm{O}_{2}$ and $2 \mathrm{mM}$ guiacol. The absorption at $470 \mathrm{~nm}$ was recorded and the activity was calculated using the extinction coefficient of $26.6 \mathrm{mM}^{-1} \cdot \mathrm{cm}^{-1}$ and expressed as $\mathrm{nmol} \mathrm{min}^{-1} \cdot \mathrm{mg}^{-1}$ protein.

\subsection{Assay of Glutathione-S-transferase (GST; EC 2.5.1.18) Activity}

The activity of GST was measured according to [29]. $1 \mathrm{~g}$ each of root and shoot samples were extracted in $100 \mathrm{mM}$ Tris- $\mathrm{HCl}$ ( $\mathrm{pH}$ 7.5) containing $2 \mathrm{mM}$ EDTA, 
$14 \mathrm{mM} \beta$-mercaptoethanol and 7.5\% PVP (w/v). After centrifugation at 15,000 g for 15 minutes, supertanants were collected. Assay of enzyme activity was performed in $100 \mathrm{mM}$ potassium phosphate buffer ( $\mathrm{pH}$ 6.5) containing $5 \mathrm{mM} \mathrm{GSH}$ and $1 \mathrm{mM}$ CDNB. The absorbance at $340 \mathrm{~nm}$ was measured and the activity of GST was calculated by the extinction coefficient of $9.6 \mathrm{mM}^{-1} \cdot \mathrm{cm}^{-1}$ and was expressed as $\mathrm{nmol} \mathrm{min}^{-1} \cdot \mathrm{mg}^{-1}$ protein.

\subsection{Phytochelatin Isolation and Analysis}

Phytochelatin analysis was performed by RP-HPLC method of [30] with slight modifications. The washed samples were frozen in liquid nitrogen. $1.5 \mathrm{~g}$ pulverized plant material was homogenized in $8 \mathrm{ml}$ ice cold $6.3 \mathrm{mM}$ DTPA containing $0.1 \%(\mathrm{v} / \mathrm{v})$ trifluoroacetic acid (TFA). The extract was centrifuged at 13,800 g, at $4^{\circ} \mathrm{C}$ for 20 minutes, filtered through a syringe filter $(0.22 \mu \mathrm{M})$. During derivatization, $450 \mu \mathrm{l}$ of $200 \mathrm{mM}$ HEPPS buffer, $\mathrm{pH} 8.2$ containing $6.3 \mathrm{mM}$ DTPA was mixed with $10 \mu \mathrm{mBBr}$ and $250 \mu \mathrm{l}$ of crude extract, followed by derivatization at $45^{\circ} \mathrm{C}$ for 30 minutes in the dark. The reaction was interrupted by adding $300 \mu \mathrm{l}$ M MSA. The samples were used for HPLC analysis. The derivatives were separated by Shimadzu Nova Pak C18 analytical column. $5 \mu$ of the derivatized sample was injected. A gradient of $0.1 \%$ TFA and $100 \%$ ACN was used as $12 \%-30 \%$ $\mathrm{ACN}$ in 22 minutes, $30 \%-55 \% \mathrm{ACN}$ from $22-45$ minutes, 55\% - 100\% ACN from 45 - 60 minutes. The flow rate was $0.7 \mathrm{ml} \cdot \mathrm{min}^{-1}$. Flourescence was monitored using a Shimadzu fluorescence detector. Excitation wavelength was 380 $\mathrm{nm}$, emission wavelength was $470 \mathrm{~nm}$. Total duration of analysis was $60 \mathrm{mi}$ nutes.

\subsection{Protein Estimation}

In all the enzyme preparations, protein contents were estimated according to [31]. For the assay, $0.1 \mathrm{ml}$ enzyme extract, $0.9 \mathrm{ml}$ buffer, $5 \mathrm{ml}$ Lowry solution (Solution A, B and C in ratio 98:1:1) were incubated for 20 minutes followed by addition of $0.5 \mathrm{ml}$ Folin ciocalteau reagent (diluted with distilled water 1:1), incubated in darkness for 10 minutes, and then read at $660 \mathrm{~nm}$. Standard curve was prepared using bovine serum albumin (BSA) as standard.

\subsection{Statistical Analysis}

All the experimental data values were means from three independent series, each done with two replicates, and the results presented as means \pm standard error (SE), based on three replications. The significance of differences between the mean values of control and arsenate/selenate grown samples were statistically evaluated by two-sided Student's t-test. The effects of stress on various parameters of wheat seedlings were considered statistically significant at $\mathrm{p} \leq 0.05$.

\section{Results}

\subsection{Influence on Seedling Growth and Water Content}

Arsenate exposure for 21 days to wheat seedlings caused a reduction in water 
contents along with reduction in root and shoot elongation. The inhibition was linear with increasing concentrations of arsenate treatment (Figures 1(a)-(c)). Compared to control, in root, the growth decreased by about 25\%, 34\% and $62 \%$ and in shoot by about $13 \%, 34 \%$ and $47 \%$ in $20 \mu \mathrm{M}, 50 \mu \mathrm{M}, 100 \mu \mathrm{M}$ arsenate treatment respectively. During joint application of arsenate with selenate, rate of growth also decreased in the treated seedlings but less than arsenate treatment alone. In root, rate of growth decreased by about $13 \%, 26 \%$ and $38 \%$ and in shoot by about $6 \%, 23 \%$ and $25 \%$ in $20,50,100 \mu \mathrm{M}$ arsenate treatment along with selenate $(10 \mu \mathrm{M})$ treatment respectively over control.

In both root and shoot water contents decreased linearly with increasing concentrations of arsenate treatment (Figure 2). Compared to control, in root, water contents decreased by about $9 \%, 36 \%$, and $54 \%$ and in shoot by about $4 \%$, $6 \%$, and $18 \%$ in $20,50,100 \mu \mathrm{M}$ arsenate treatment respectively. Selenate application along with same levels of arsenate was found to exhibit very little increase in water contents in both root and shoot with respect to seedlings having only arsenic treatment (Figure 2).
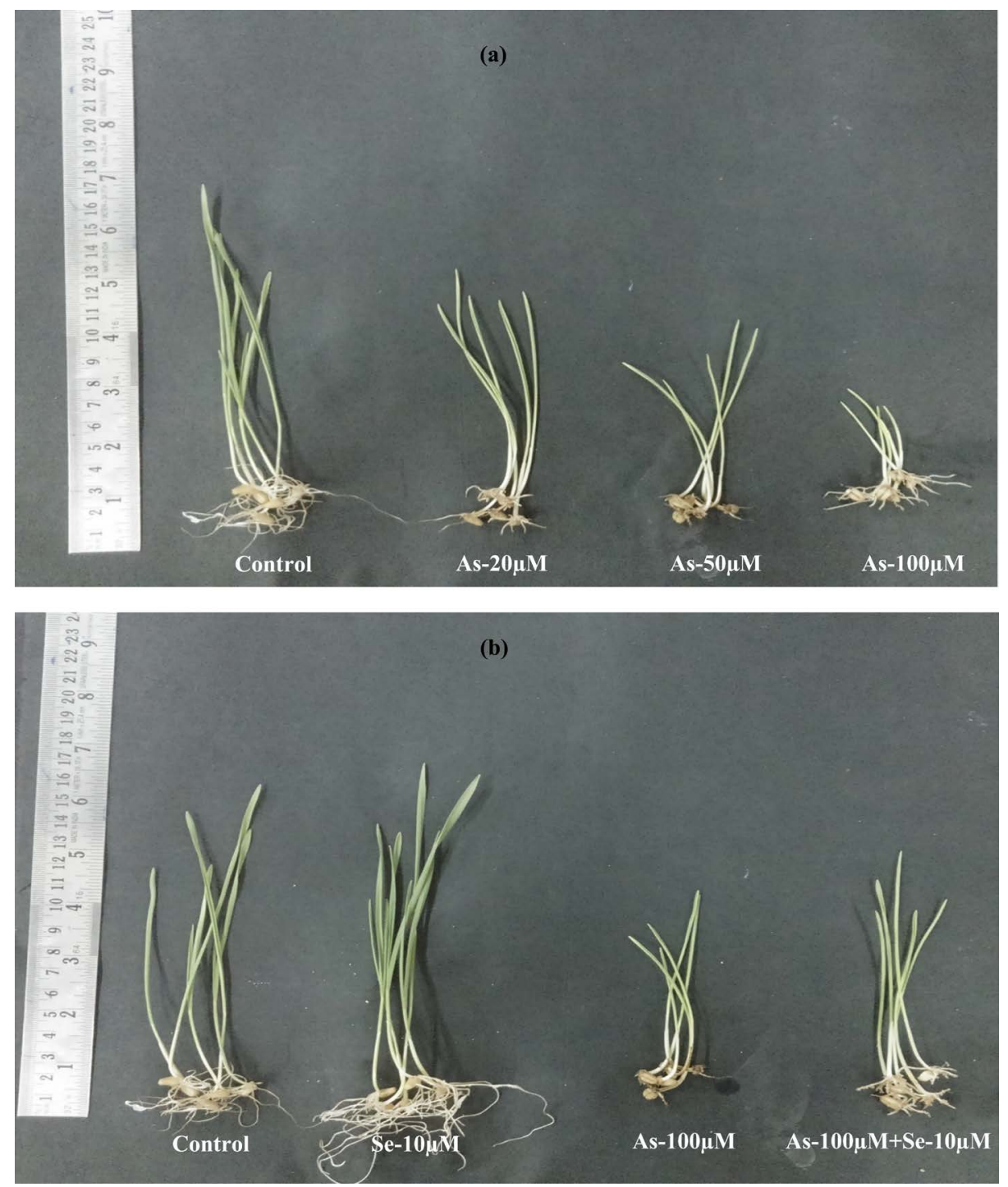


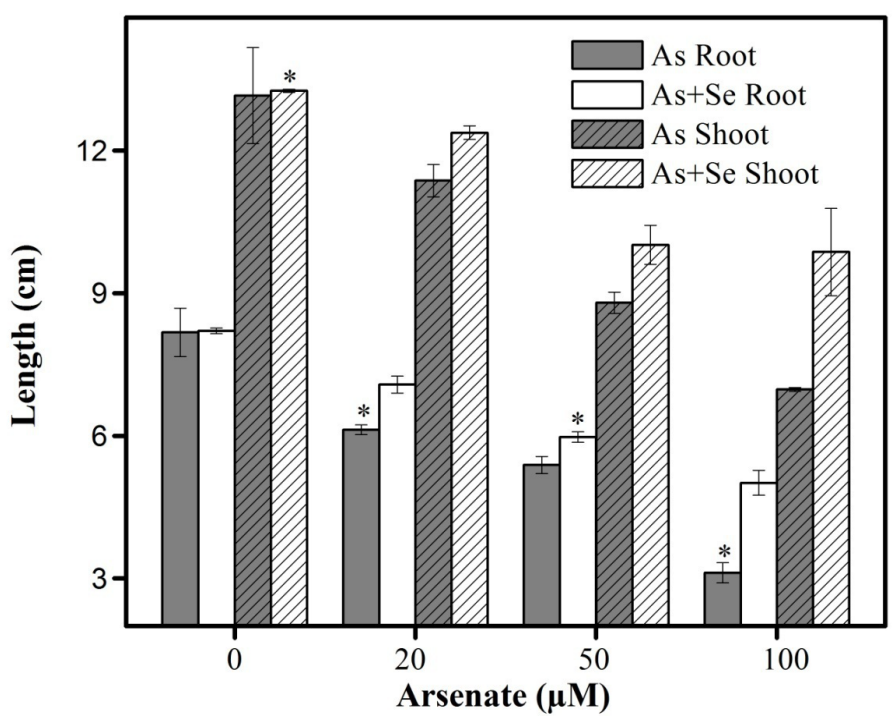

(c)

Figure 1. (a) (b) Effect of various concentrations of arsenate and $10 \mu \mathrm{M}$ concentration of selenate applied either alone or in their combination on the growth of wheat (PBW-343) seedling after 48 hours of germination. Seedlings were exposed to 16 hour photoperiod for 19 days in presence of modified Hoagland solution, $\mathrm{pH} 7.2$; (c) Effect of various concentrations of arsenate and $10 \mu \mathrm{M}$ concentration of selenate applied either alone or in their combination on the growth of wheat (PBW-343) seedling after 48 hours of germination. Seedlings were exposed to 16 hour photoperiod for 19 days in presence of modified Hoagland solution, $\mathrm{pH}$ 7.2. The values are means of 3 experiments \pm SE. *indicates significant at $\mathrm{p} \leq 0.05$.

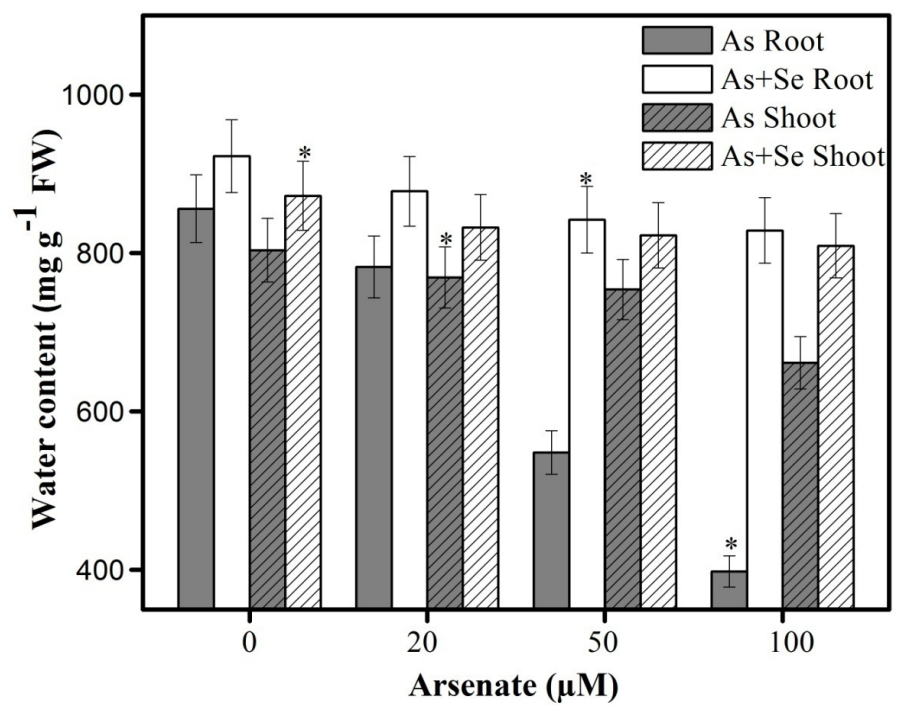

Figure 2. Effect of arsenate and selenate applied either alone or in their combination on the water content in root and shoot of 21 days old wheat (PBW-343) seedlings. The values are means of 3 experiments \pm SE. ${ }^{*}$ indicates significant at $\leq 0.05$.

\subsection{Arsenic and Selenium Contents}

The arsenic contents in the arsenate treated 21 days old test seedlings were increased significantly compared to control. The increment was linear with the increasing concentrations of arsenate and was most in $100 \mu \mathrm{M}$ arsenate treated 
seedlings and least in $20 \mu \mathrm{M}$ treated seedlings. The accumulation of arsenate in roots was more than the shoots (Figure 3). During joint application of arsenate and selenate, the arsenic contents were less in the test seedlings, compared to the seedlings that were treated with arsenate alone.

The selenium contents in the arsenate treated test seedlings was below the detection level. During joint application of selenate with arsenate, the selenium contents were higher in the test seedlings compared to the seedlings that were treated with arsenate alone. The accumulation of selenium was more pronounced in roots than in shoots (Figure 4).

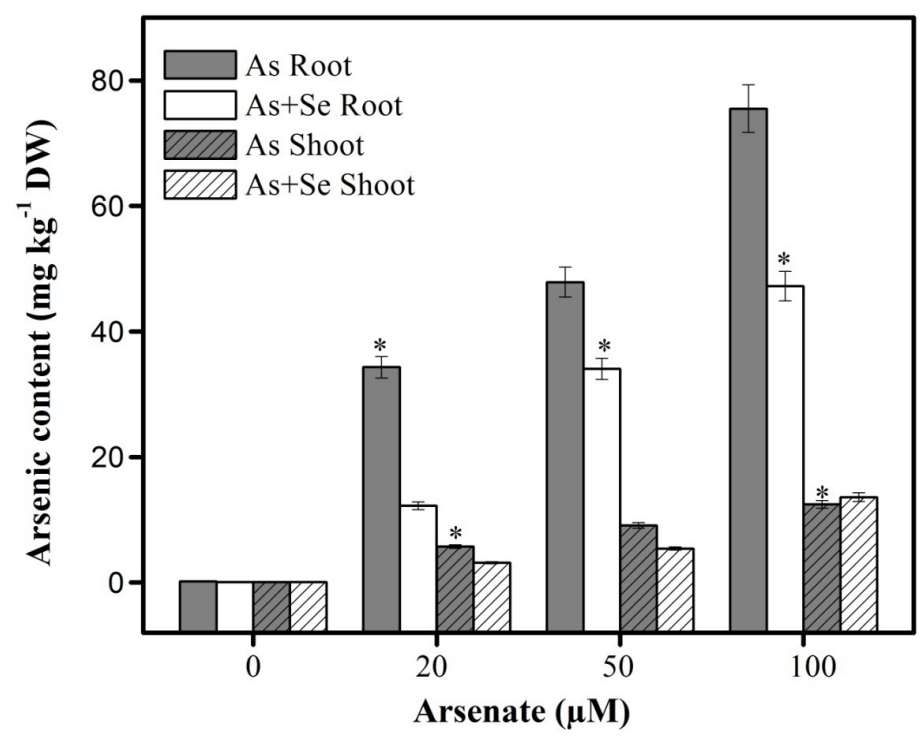

Figure 3. Effect of arsenate and selenate applied either alone or in their combination on the arsenic contents in roots and shoots of 21 days old wheat (PBW-343) seedlings. The values are means of 3 experiments $\pm \mathrm{SE}$. ${ }^{*}$ indicates significant at $\mathrm{p} \leq 0.05$.

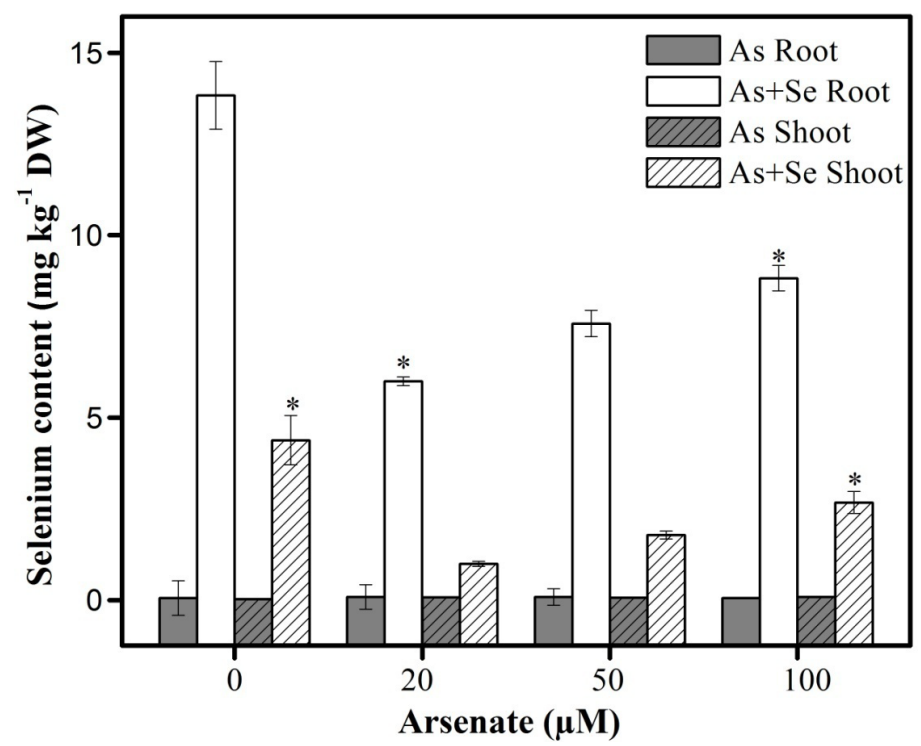

Figure 4. Effect of arsenate and selenate applied either alone or in their combination on the selenium contents in roots and shoots of 21 days old wheat (PBW-343) seedlings. The values are means of 3 experiments \pm SE. ${ }^{*}$ indicates significant at $\mathrm{p} \leq 0.05$. 


\subsection{AOX and APX Activities}

In the test seedlings the activity of AOX was significantly increased with the increasing concentrations of arsenate treatment (Figure 5). Compared to control, in root, the activity of AOX increased by about $61 \%, 82 \%$, and $115 \%$ and in shoot by about $17 \%, 38 \%$, and $82 \%$ in $20,50,100 \mu \mathrm{M}$ arsenate treatment respectively. During the joint application of arsenate with selenate, the activity of AOX was also increased in all treated seedlings but less than arsenate treatment alone. In roots, the said activity increased by about $31 \%, 55 \%$, and $81 \%$ while in shoot that were about $18 \%, 22 \%$, and $28 \%$ in $20,50,100 \mu \mathrm{M}$ arsenate along with $10 \mu \mathrm{M}$ concentration of selenate treatment respectively over control.

Similarly, in the test seedlings the activity of APX was significantly increased (Figure 6). Compared to control, in root, the activity of APX increased by about $37 \%, 87 \%$, and $101 \%$ and in shoot by about $47 \%, 89 \%$, and $110 \%$ in $20,50,100$ $\mu \mathrm{M}$ arsenate treatment respectively. During the joint application of arsenate with selenate, the activity of APX was also increased in the test seedlings but less than arsenic treatment alone. In roots, the activity of the said enzyme was increased by about $25 \%, 47 \%$, and $90 \%$ while in shoots that were about $37 \%, 67 \%$, and $87 \%$ in $20,50,100 \mu \mathrm{M}$ arsenate along with selenate treatment respectively.

\subsection{Ascorbate Contents}

In the test seedlings the total ascorbate contents were significantly decreased by arsenate treatment (Figure 7). Compared to control, in root, the level of ascorbate decreased by about $19 \%, 31 \%$, and $35 \%$ and in shoot by about $13 \%, 21 \%$, and $33 \%$ in $20,50,100 \mu \mathrm{M}$ arsenate treatment respectively. During application of arsenate with selenate, the ascorbate contents were also decreased in all treated seedlings compared to control but more than arsenic treatment alone. In roots, the ascorbate contents decreased by about $8 \%, 16 \%$, and $23 \%$ while in shoot that

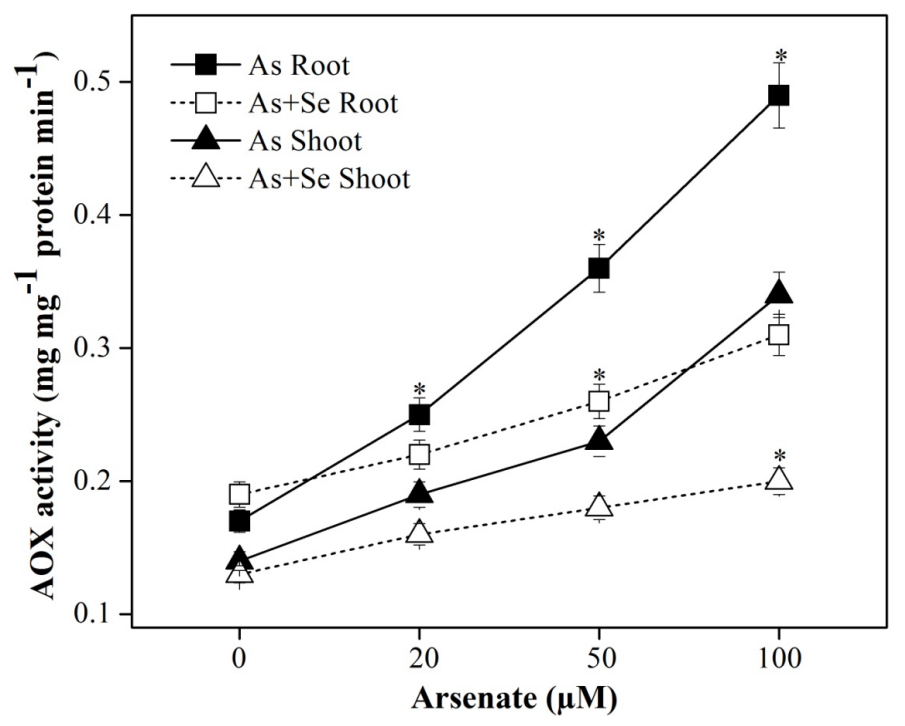

Figure 5. Effect of arsenate and selenate applied either alone or in their combination on the AOX activity in roots and shoots of 21 days old wheat (PBW-343) seedlings. The values are means of 3 experiments \pm SE. ${ }^{*}$ indicates significant at $\mathrm{p} \leq 0.05$. 


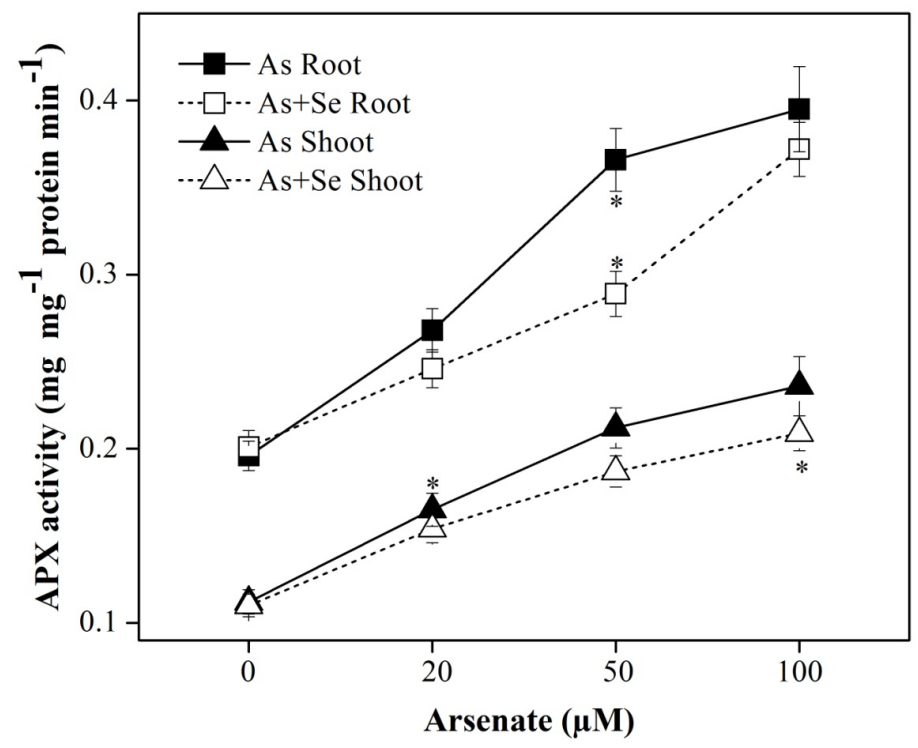

Figure 6. Effect of arsenate and selenate applied either alone or in their combination on the APX activity in roots and shoots of 21 days old wheat (PBW-343) seedlings. The values are means of 3 experiments \pm SE. ${ }^{*}$ indicates significant at $\mathrm{p} \leq 0.05$.

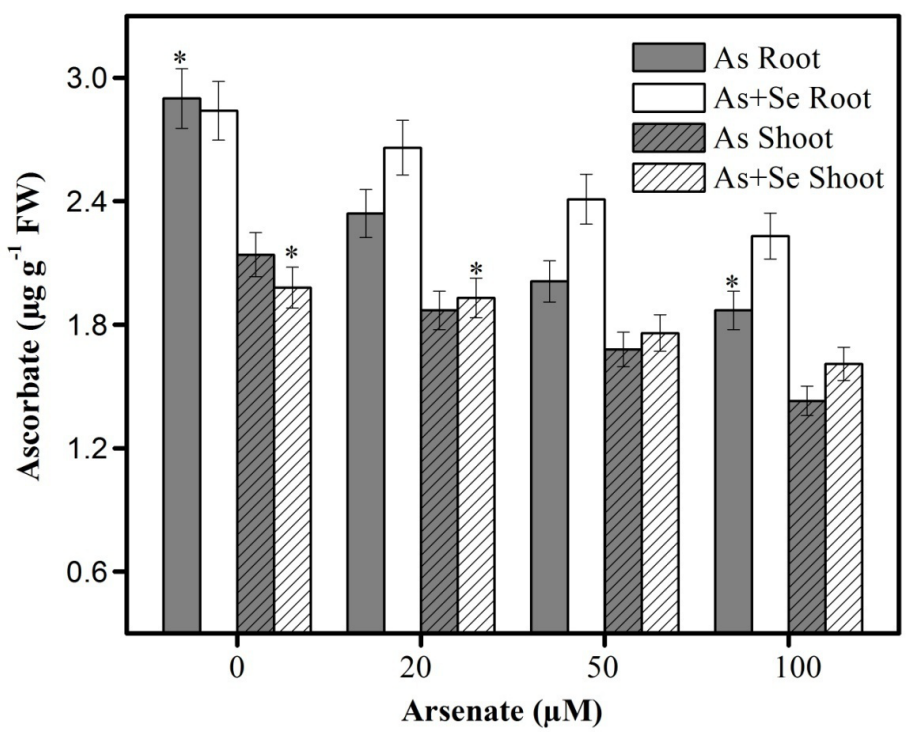

Figure 7. Effect of arsenate and selenate applied either alone or in their combination on the ascorbate content in roots and shoots of 21 days old wheat (PBW-343) seedlings. The values are means of 3 experiments \pm SE. ${ }^{*}$ indicates significant at $\mathrm{p} \leq 0.05$.

by about $10 \%, 18 \%$, and $25 \%$ in $20,50,100 \mu \mathrm{M}$ arsenate along with $10 \mu \mathrm{M}$ selenate treatment respectively.

\section{5. $\alpha$-Tocopherol Contents}

The total $\alpha$-tocopherol contents were significantly increased in the test seedlings by arsenate treatment (Figure 8). Compared to control, in root, the level of $\alpha$-tocopherol increased by about $34 \%, 104 \%$, and $142 \%$ and in shoot by about $26 \%, 54 \%$, and $69 \%$ in $20,50,100 \mu \mathrm{M}$ arsenate treatment respectively. During application of arsenate with selenate, the $\alpha$-tocopherol contents were also in- 
creased in all treated seedlings compared to control but less than arsenic treatment alone. In roots, the $\alpha$-tocopherol contents decreased by about $18 \%, 79 \%$, and $105 \%$ while in shoot that by about $16 \%, 41 \%$, and $52 \%$ in $20,50,100 \mu \mathrm{M}$ arsenate along with selenate treatment respectively.

\subsection{Total Glutathione (GSH) Contents}

The total glutathione contents were significantly increased in the test seedlings by arsenate treatment (Figure 9). Compared to control, in roots, the level of glutathione increased by about $61 \%, 82 \%$, and $115 \%$ and in shoots by about $43 \%$,

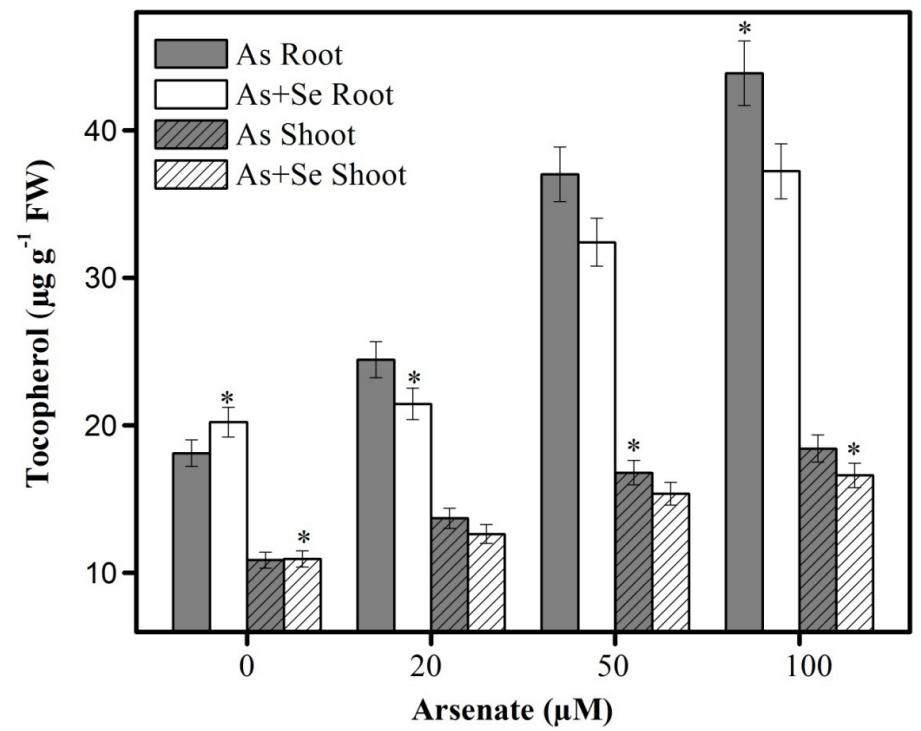

Figure 8. Effect of arsenate and selenate applied either alone or in their combination on the $\alpha$-tocopherol content in roots and shoots of 21 days old wheat (PBW-343) seedlings. The values are means of 3 experiments \pm SE. ${ }^{*}$ indicates significant at $\mathrm{p} \leq 0.05$.

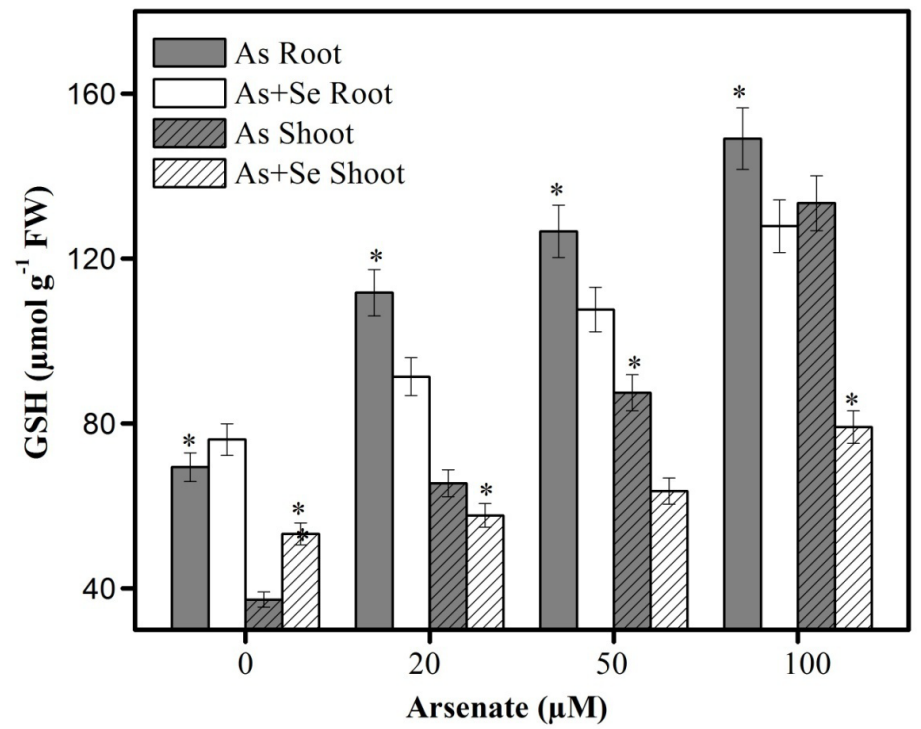

Figure 9. Effect of arsenate and selenate applied either alone or in their combination on the total glutathione content in roots and shoots of 21 days old wheat (PBW-343) seedlings. The values are means of 3 experiments \pm SE. ${ }^{*}$ indicates significant at $\mathrm{p} \leq 0.05$. 
$58 \%$, and $72 \%$ in $20,50,100 \mu \mathrm{M}$ arsenate treatment respectively. During combined application of arsenate with selenate, the glutathione contents were also increased in all treated seedlings but less than arsenic treatment alone. In roots the glutathione contents increased by about $31 \%, 55 \%$, and $84 \%$ while in shoots by about $35 \%, 41 \%$, and $52 \%$ in $20,50,100 \mu \mathrm{M}$ arsenate along with $10 \mu \mathrm{M}$ selenate treatment respectively.

\subsection{Influence on GR, GPx and GST Activities}

In the arsenate treated test seedlings the activity of GR was significantly increased (Figure 10(a)). Compared to control, in roots, the activity of GR increased by about $17 \%, 35 \%$ and $66 \%$ and in shoots by about $66 \%, 87 \%$, and $158 \%$ in $20,50,100 \mu \mathrm{M}$ arsenate treatment respectively. But joint application of arsenate with selenate, the activity of GR was also increased in the shoots but less

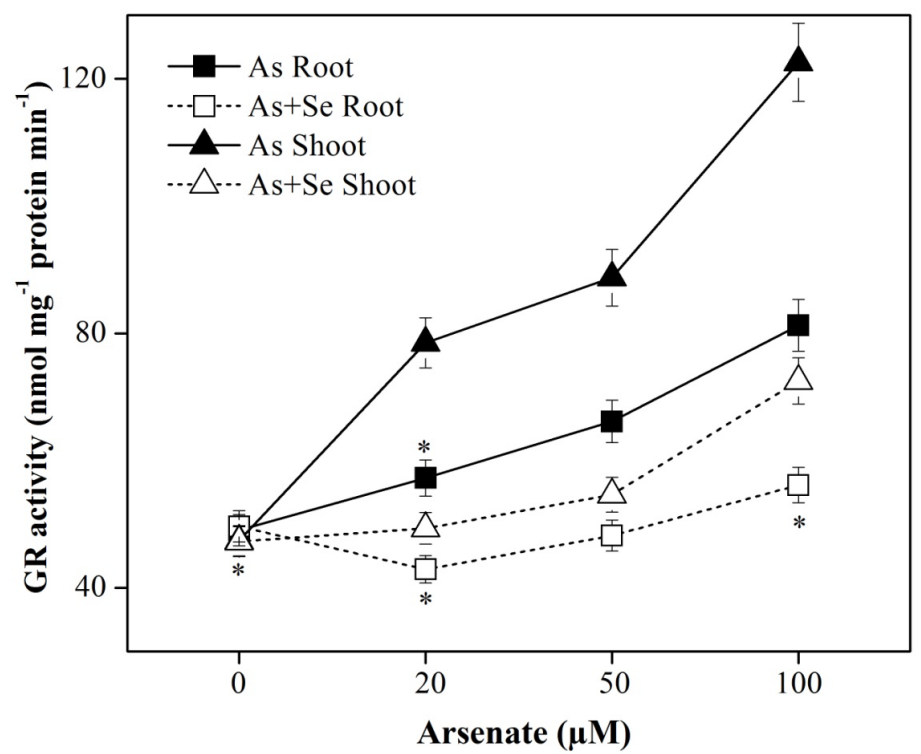

(a)

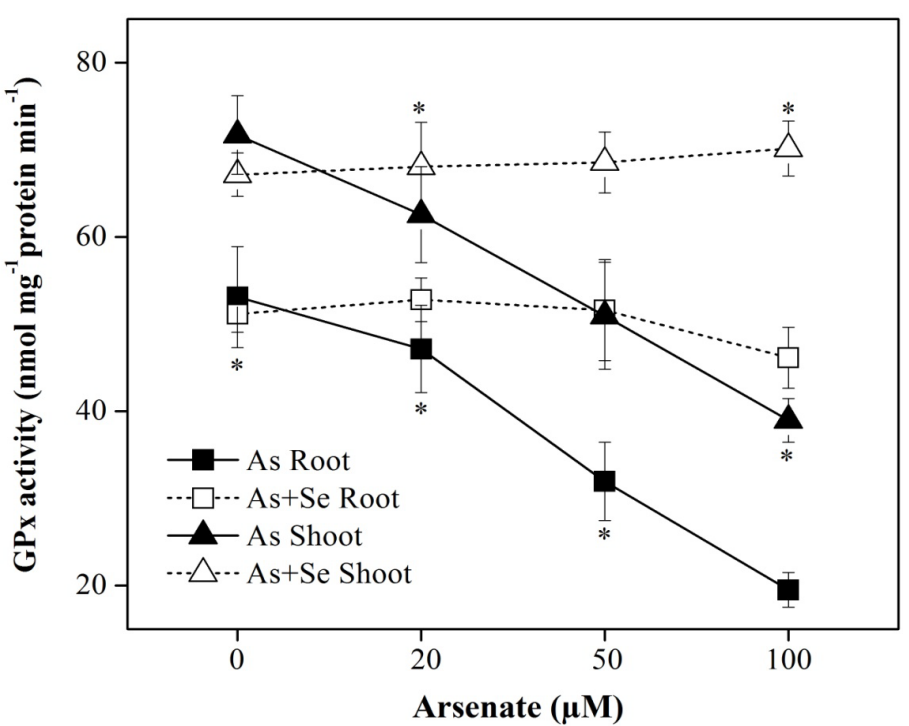

(b) 


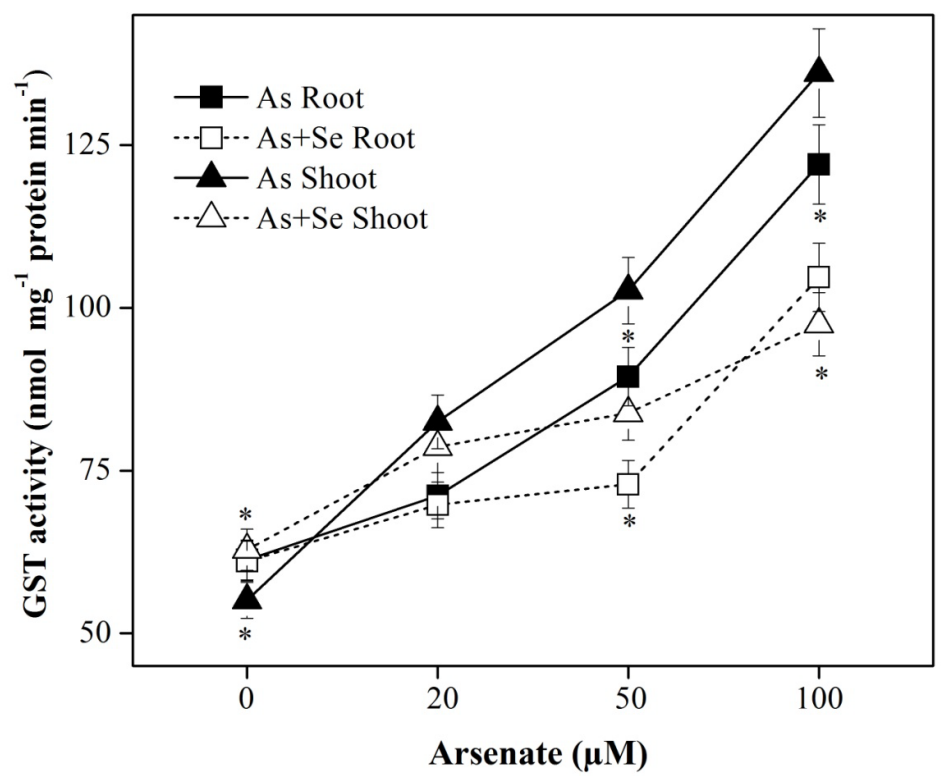

(c)

Figure 10. (a) Effect of arsenate and selenate applied either alone or in their combination on the GR activity in roots and shoots of 21 days old wheat (PBW-343) seedlings. The values are means of 3 experiments \pm SE. ${ }^{*}$ indicates significant at $\mathrm{p} \leq 0.05$; (b) Effect of arsenate and selenate applied either alone or in their combination on the GPx activity in roots and shoots of 21 days old wheat (PBW-343) seedlings. The values are means of 3 experiments $\pm S E .^{*}$ indicates significant at $\mathrm{p} \leq 0.05$; (c) Effect of arsenate and selenate applied either alone or in their combination on the GST activity in roots and shoots of 21 days old wheat (PBW-343) seedlings. The values are means of 3 experiments \pm SE. ${ }^{*}$ indicates significant at $\mathrm{p} \leq 0.05$.

than arsenic treatment alone, while in roots, activity of the enzyme was decreased in arsenate treatment over control. In shoots, GR activity increased by about $4 \%, 15 \%$ and $53 \%$ and in roots it decreased by about $13 \%, 2 \%$, and $1 \%$ in 20, 50, $100 \mu \mathrm{M}$ arsenate along with $10 \mu \mathrm{M}$ selenate treatment respectively.

The activity of GPx in the test seedlings was decreased by arsenate treatment (Figure 10(b)). Compared to control, in roots, the activity of GPx decreased by about $11 \%, 40 \%$, and $63 \%$ and in shoot by about $13 \%, 29 \%$, and $46 \%$ in 20,50 , $100 \mu \mathrm{M}$ arsenate treatment respectively. During application of arsenate with selenate, the activity of GPx was altered in all test seedlings compared to only arsenate treatment. Compared to control, the activity of GPx decreased in roots but increased in shoots very little in stipulated concentrations of arsenate and selenate treatment.

In the test seedlings, the activity of GST was increased by arsenate treatment (Figure 10(c)). Compared to control, in roots, the activity of GST increased by about $16 \%, 46 \%$, and $99 \%$ and in shoots by about $50 \%, 86 \%$, and $147 \%$ in 20,50 , $100 \mu \mathrm{M}$ arsenate treatment respectively. During the joint application of arsenate with selenate, the activity of GST was also increased in all treated seedlings compared to control but less than arsenic treatment alone. In roots, the GST activity increased by about $14 \%, 19 \%$, and $71 \%$ while in shoots that were about $53 \%, 52 \%$, and $77 \%$ in $20,50,100 \mu \mathrm{M}$ arsenate and $10 \mu \mathrm{M}$ selenate treatment 
respectively.

\subsection{Phytochelatin Contents}

The chromatograms of phytochelatins obtained from the arsenate and selenate treated root and shoot are shown in Figure 11(a) \& Figure 11(b). In untreated root and shoot samples, only $\mathrm{mBBr}$ satellite peaks along with low intensity PC2 and PC4 peaks were detected. In arsenate treated samples however, there were
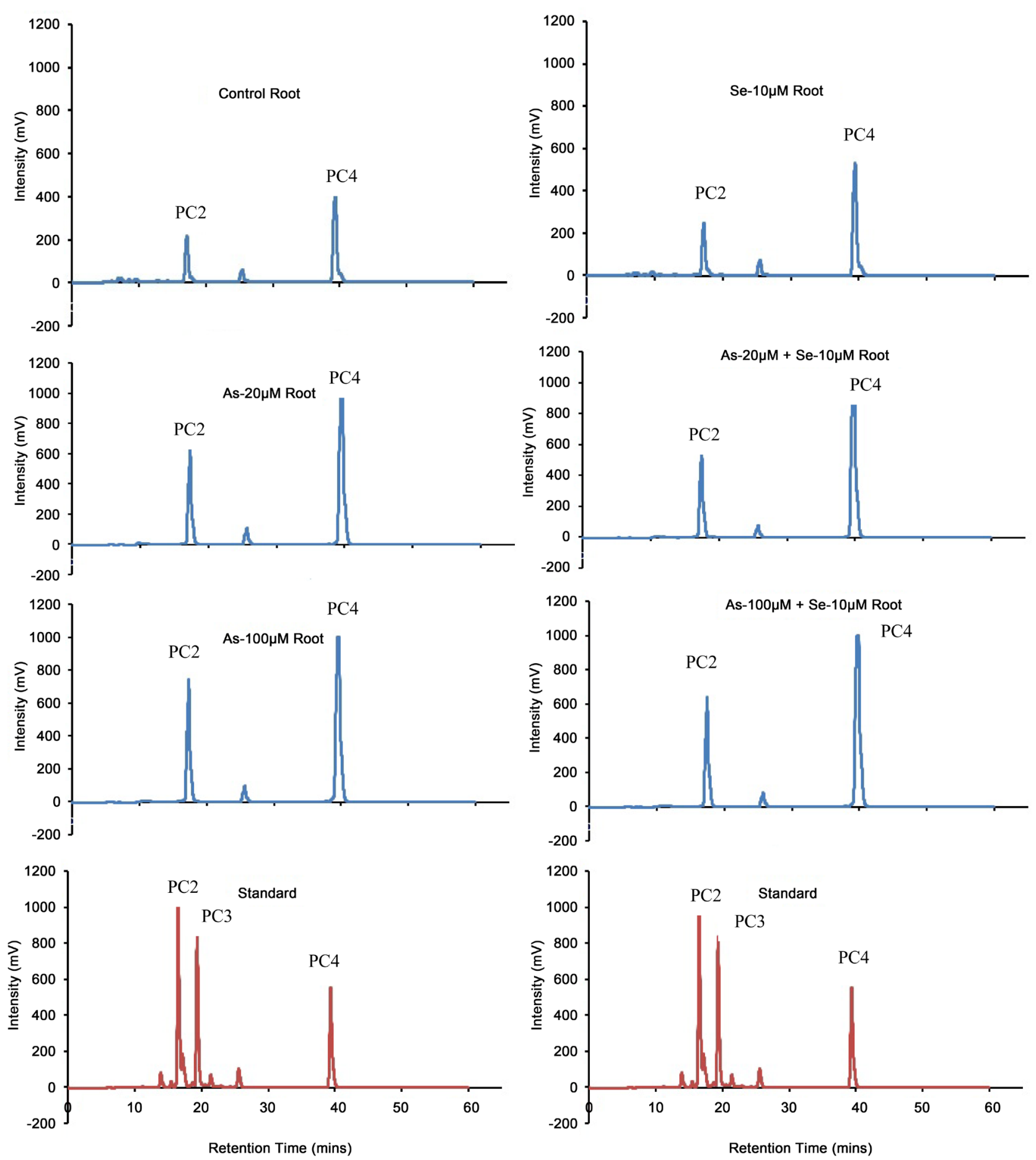

(a) 

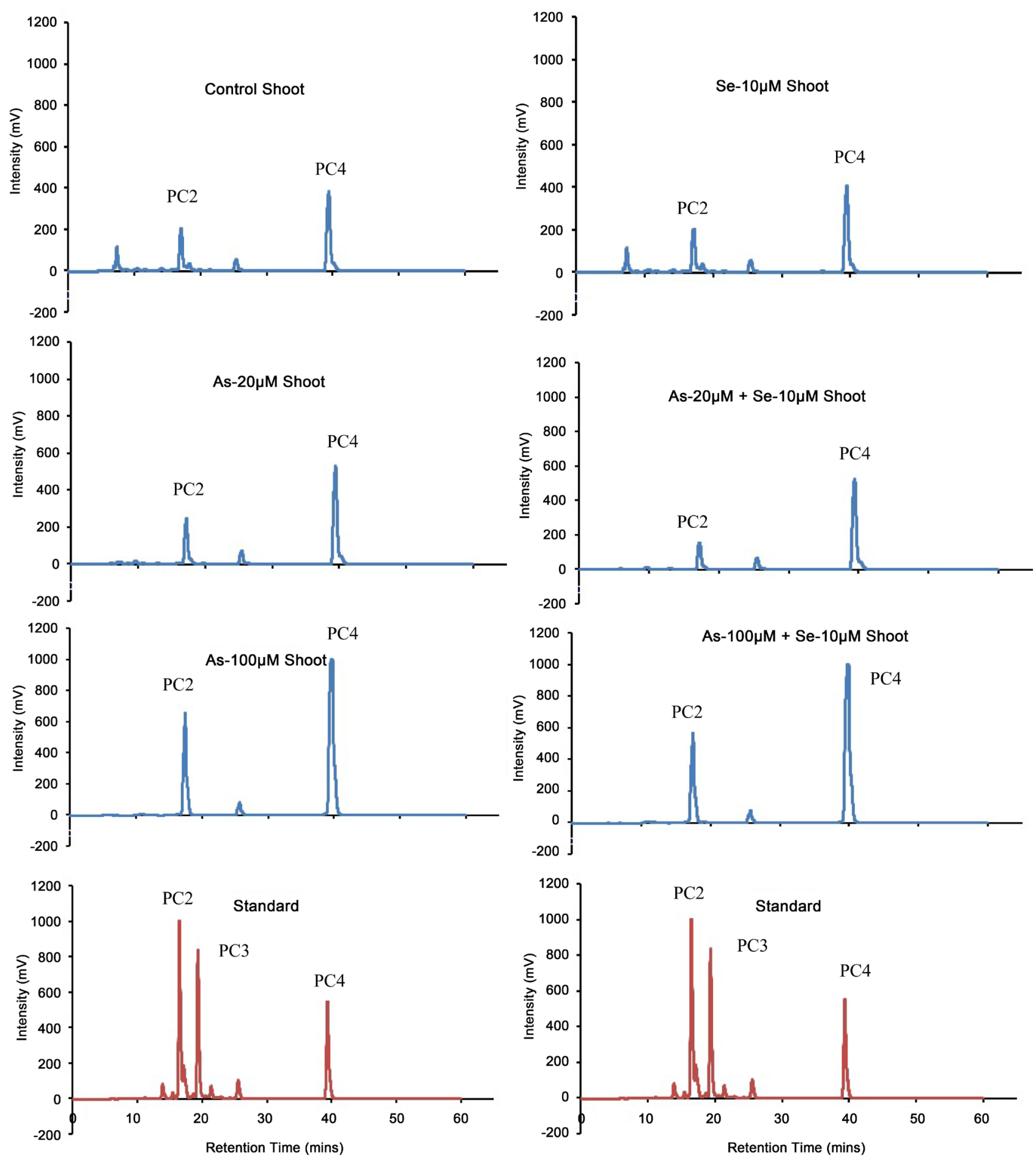

(b)

Figure 11. (a) HPLC chromatogram of phytochelatins (PC) from 21 days old root samples of arsenate and selenate treated 21 days old wheat (PBW-343) seedlings. Retention time of PC2 is 16 mins., PC3 is 19 mins. and PC4 is 40 mins; (b) HPLC chromatogram of phytochelatins (PC) from 21 days old shoot samples of arsenate and selenate treated 21 days old wheat (PBW-343) seedlings. Retention time of PC2 is 16 mins., PC3 is 19 mins. and PC4 is 40 mins.

two thiol peaks for PC2 and PC4 that appeared beside the monothiols Cys, and GSH with retention time (RT) at 16 and 40 minutes respectively. In addition, the chromatograms of the individual PC2, PC3 and PC4 standards were included for 
the peak identification. The two unknown peaks with RT of approximately 16 minutes and 40 minutes were identified as PC2 and PC4 respectively after comparison with the standard mixture. The height of peak for PC2 was stimulated by increasing arsenic $(20 \mu \mathrm{M}$ and $100 \mu \mathrm{M})$ exposure in both root and shoot of the seedlings, whereas the PC4 peak height remained fairly constant. During the joint application of arsenate with selenate, the two thiol peaks were again observed but peak heights were less than arsenic treatment alone. The PC3 peak at 19 minutes was not observed in the test seedlings.

\section{Discussion}

\subsection{Influence of Arsenic and Selenium Accumulation on Growth and Water Content}

It was observed that there was a gradual increase in accumulation of arsenic in the test seedlings with increasing concentrations of arsenate. Thus arsenic applied in the form of arsenate entered in the plant system, which affected growth and metabolism of the seedlings (Figure 3). Arsenic accumulation differed in different parts of the test seedlings [32]. The roots showed more arsenic accumulation in comparison to shoots. These observations were supported by [33] in sugarbeet and [34] in radish. On joint application of arsenate with selenate, the accumulation of arsenic in the test seedlings was lowered thereby showing tolerance in the plants [11]. Similarly, selenium in form of selenate entered the plants and was also able to check arsenic entry providing tolerance to the plants.

Exposures to arsenic significantly altered both root and shoot growth of the wheat seedlings. The rate of inhibition linearly increased with increasing concentrations of arsenic (Figures 1(a)-(c), Figure 2). The reduction in root growth by arsenic treatment in various test seedlings has been reported by a number of investigators [10] [35] [36]. The roots were inhibited to a greater extent than the shoots possibly due to higher As accumulation in roots as in nutrient media the roots are the first point of contact with the toxic arsenic species. The reduction of shoot growth is dependent on the reduction of root growth [37]. Arsenate causes several deleterious morphological effects on different stages of plant growth and development [38]. The effects of arsenate on plant growth are associated with low osmotic potential and nutrient imbalance.

The rate inhibition of root and shoot growth as well as water content was lowered by the joint application of arsenic with selenium. Thus selenium has an ameliorating effect on arsenic induced toxicity [4] [9].

\subsection{Role of AOX and APX under Stress}

AOX and APX are important enzymatic defense systems in plants which maintain the function of ascorbate-glutathione cycle to combat enhanced generation of ROS. AOX oxidizes ascorbic acid, producing dehydroascorbic acid and water. During abiotic stress, this enzyme becomes active to protect plant cells. In the present study, an increase in the AOX activity was noticed in the test seedlings in 
response to arsenate. APX, mainly present in the plastid stroma and membrane, removes $\mathrm{H}_{2} \mathrm{O}_{2}$ through ascorbate-glutathione pathway. In this cycle, superoxide is converted to $\mathrm{H}_{2} \mathrm{O}_{2}$ by SOD. $\mathrm{H}_{2} \mathrm{O}_{2}$ is removed by APX forming monodehydroascorbate which spontaneously dismutate to ascorbate and dehydroascorbate. Peroxidase requires a reductant to reduce $\mathrm{H}_{2} \mathrm{O}_{2}$ into water; in plant cell this reducing agent is ascorbate [39]. Enhanced production of oxygen free radical is responsible for stress dependent peroxidation of membrane lipids. Increased peroxidase activity degrades toxic substances like peroxide and phenols in plants. In the test seedlings treated with arsenate, there was elevation in the activity of APX. Upregulation of APX activity has been reported in arsenic exposed rice [40], mung bean [41], beans [42] and maize [43]. Therefore, increased activities of the enzymes observed in the present study provide circumstantial evidence for enhanced production of oxygen free radicals.

\subsection{Influence of Ascorbate to Combat Stress}

Plants have two component systems for regulating the balance of $\mathrm{H}_{2} \mathrm{O}_{2}$, and therefore of ROS, within cells. One component includes a group of non-enzymatic antioxidants such as GSH, PC, ascorbate, carotenoids, and anthocyanin. Ascorbate and GSH are unique among the non-enzymatic antioxidants in that they can form a redox cycle. The ROS generated during As exposure induces an increase in the oxidation state of the redox active pools of ascorbate and GSH [44]. Superoxide and the hydroxyl radical can directly oxidize both ascorbate and GSH, which act as nucleophilic scavengers. The synthesis of ascorbate, GSH and $\mathrm{PC}$ increases in the plant, particularly in the roots [45] during As exposure. The second component of the two-components is $\mathrm{H}_{2} \mathrm{O}_{2}$ neutralizing system, composed of monodehydroascorbate reductase, dehydroascorbate reductase and glutathione reductase. Together, these enzymes efficiently recycle oxidized GSH and ascorbate to allow further cycles of $\mathrm{H}_{2} \mathrm{O}_{2}$ reduction. Ascorbate is the most abundant antioxidant present in stroma of chloroplast, apoplast, cytosol as well as vacuole of plant cell and have important role as electron donors. Ascorbate pool in chloroplast contains a bulk of reduced ascorbate which protects photosynthetic machinery, and has an important role in the removal of $\mathrm{H}_{2} \mathrm{O}_{2}$ and regeneration of membrane bound carotenoids and $\alpha$-tocopherol via the ascorbate-glutathione cycle. It can react directly by reducing superoxide, $\mathrm{H}_{2} \mathrm{O}_{2}$ and hydroxyl radical or quenching singlet oxygen [44] in a non enzymatic pathway [46]. Ascorbate (reduced) also functions as a co-factor of APX enzyme, which produces dehydroascorbate (oxidized). Since it is hydrophilic in nature, it can scavenge free radicals in the aqueous phase of the cell. Ascorbate concentration increased in hypocotyls, whereas decreased in roots of cucumber plants exposed to arsenic [47]. Our results have demonstrated that the ascorbate contents of wheat seedlings was profoundly decreased with arsenate treament. This decrease was mainly due to either reduction of DHAR activity or increase in APX activity. However, joint application of arsenate with selenate increased the level of ascorbate than those of arsenic treated seedlings. 


\subsection{Influence of $\alpha$-Tocopherol to Regulate Stress}

A number of vitamins have been found to reduce the toxic symptoms of heavy metals including arsenic [48] [49]. Vitamin E in the generic term used to describe atleast eight natural occurring compounds that possess the biological activity of $\alpha$-tocopherol. It is a low molecular mass antioxidant, interacts directly with the oxidizing radicals and protects the cells from ROS [50]. In our experiment the $\alpha$-tocopherol level increased with the application of arsenate but decreased during its joint application with selenate. The lipid soluble, non enzymatic antioxidant, $\alpha$-tocopherol checks the lipid peroxidation through limiting the propagation of chain reaction of lipid peroxidation [51]. Vitamin E, as a scavenger of free radicals, might be reacting with methyl radicals that might be formed in the breakdown to provide protection. Additionally vitamin E may also alleviate arsenic toxicity [52]. The protective mechanism of vitamin $\mathrm{E}$ against stress could be attributed to its antioxidant property and its ability to stabilize membrane by interacting with unsaturated fatty acid chain [53].

\subsection{Role of Glutathione to Regulate Stress}

Thiols, including cysteine, GSH, and PCs, play a major role in the maintenance of redox status of the cell as well as in the detoxification of metals and metalloids. An increase in its content may be attributed to an induction of the whole sulphur assimilation pathway, from sulfate transporters to enzymes involved in the assimilation into GSH and PCs. Glutathione exists in two forms, reduced GSH and oxidized GSSG. The reduction potential of glutathione depends on the intracellular GSH/GSSG ratio. Change in the redox ratio of glutathione mainly depends on the $\mathrm{pH}$ and total GSH concentration [54]. GSH, a low molecular weight thiol is an important constituent of plant defense system during the environmental stress. It is a redox buffer present abundantly in the plant cells. GSH is one of the major sources of non-protein thiols in most plant cells. The chemical reactivity of the thiol group of GSH makes it particularly suitable to serve a broad range of biochemical functions in all organisms. The nucleophilic nature of the thiol group is important in the formation of mercaptide bond with metals and for reacting with selected electrophiles. This reactivity along with the relative stability and high water solubility of GSH makes it an ideal biochemical to protect plants against various stresses. It has been suggested that the GSH/GSSG ratio, an indicative of the cellular redox balance, may be involved in ROS perception. Typically, the GSH to GSSG ratio is quite high during unstressed conditions, and upon As exposure, this ratio shifts towards GSSG This shift results in the activation of signalling pathways that lead to programmed cell death, an important mechanism of stress resistance. A reducing intracellular environment is needed to maintain protein structure and function. A high GSH/GSSG ratio is maintained by GR.

GSH is related to defense pathways such as phytochelatin synthesis and ascorbate-glutathione cycle. Arsenate is known to have a high affinity for all thiols [55]. The reduction of arsenate to arsenite is catalyzed by arsenate reductase as a 
mechanism involved in detoxification because arsenite can more easily bind with phytochelatins. Arsenate reduction is coupled to NADPH oxidation via the reduction of GSSG by GR, with the resulting GSH serving as the electron donor for arsenate reductase [56]. GSH is a key component of the antioxidant network that scavenges ROS, either directly by binding with ROS and detoxifies it through a reaction catalyzed by GSTs or indirectly by participating in the ascorbate-glutathione cycle [12]. Rapid arsenate influx resulted in glutathione depletion and phytochelatin production in Holcus lanatus [36]. Significant increase in GSH and PCs upon arsenic exposure has been demonstrated in Hydrilla verticillata [8]. [44] reported that protection from oxidative damage by a greater level of ascorbate-glutathione pool is linked with arsenate tolerance in arsenic hyperaccumulator Pteris vittata. With the application of arsenic, the GSH levels also increases significantly in the cells of arsenic sensitive plants. This was supported by the fact that GSH plays a central role in protecting cells against arsenic stress [13]. This can be supported from the results obtained in our study.

\subsection{Role of GR, GPx and GST to Combat Oxidative Stress}

GR mainly operates in the chloroplasts and catalyzes the reduction of GSSG to GSH with the accompanying oxidation of NADPH. GR plays an essential role in cell's defense against ROS by maintaining the reduced status of glutathione. The activity of GR increases with the application of arsenic stress. This is because GR plays an important role in the detoxification of arsenic induced ROS, possibly via the glutathione-ascorbate cycle. The increment of GR activity is supported by other investigators too. Enhanced GR activity results in higher amount of GSH production, associated with an increase in ascorbate contents and thus better protection against oxidative stress [57]. A decrease in GR activity can affect the GSH/GSSG ratio, decrease the ascorbate pool and has impact on ascorbate redox state with an overall decrease in stress tolerance. Arsenic mediated oxidative stress causes cellular, molecular and physiological disturbances in various plant species [58]. An increase in GR activity alone is not sufficient to confer stress tolerance. More likely, a coordinated and finely regulated action of all enzymes of the ascorbate-glutathione cycle in conjunction with that of other ROS-processing enzymes in all cell compartments is required for plant stress tolerance.

GPx are important antioxidant enzymes in plants present in different subcellular organelles. Their principal activity is to catalyze the reduction of excess $\mathrm{H}_{2} \mathrm{O}_{2}$, organic hydro peroxides (ROOHs), and lipid hydroperoxides to $\mathrm{H}_{2} \mathrm{O}$ and alcohol using GSH and/or other reducing equivalents. GPx acts upon $\mathrm{H}_{2} \mathrm{O}_{2}$ and forms GSSG that is further reduced to GSH by GR. [59] demonstrated that there was a decline in GPx activity after 15 days in response to arsenate in tomato plant which is in accordance to our results observed in arsenate treated wheat seedlings.

GST is a superfamily of multifunctional enzymes known for their role in the enzymatic detoxification of xenobiotics. It is a ubiquitous enzyme induced by toxic metals and oxidative stress, performing a range of functional roles using 
GSH as a coenzyme. GSH protects the plants against a range of toxicants by conjugating them or their metabolites through GSTs [60]. GSTs catalyze the conjugation of toxic molecules with reduced glutathione (GSH) and target them for ATP-dependent transport into the vacuole. An upregulation of upto 10 - 15 different GSTs has been demonstrated upon arsenate exposure in rice seedlings [61] [62]. The GSH-dependent catalytic functions of GST include the conjugation and resulting detoxification of cytotoxic products. GST acts by catalyzing the conjugation of GSH with electrophilic, often hydrophobic toxic compounds to form derivatives that can be secreted from the cell, sequestered in the vacuole, or catabolized. In our study, the level of GST increased linearly with the increasing concentrations of arsenic [63]. Activation of enzymatic antioxidants like GR, GST, GPx are reported to neutralize arsenic mediated oxidative stress in plants [64].

\subsection{Phytochelatin and Detoxification Mechanism}

Phytochelatins (PCs) are low molecular mass, cysteine-rich polypeptides that exhibit high affinity to chelate various metals, such as, e.g. $\mathrm{Cd}, \mathrm{Cu}, \mathrm{Zn}, \mathrm{As}$. The oligomerization of GSH to produce PC is also induced during As exposure by phytochelatin synthase activity [45]. Higher levels of GSH and phytochelatins lead to more efficient metal sequestration. The PCs form a group of structures consisted of different number of $\gamma$-Glu-Cys dipeptide units followed by a terminal Gly having general structure can be shown as ( $\gamma$-Glu-Cys) $n$-Gly with $\mathrm{n}=$ 2 - 11. Depending on the number of $\gamma$-Glu-Cys units, PCs are classified as PC2, PC3, PC4 and so on. Phytochelatins can increase the ability of plants to detoxify the toxicity by binding with arsenic and maintain ionic homeostatis. It is evident from the analysis of HPLC chromatogram peaks that arsenate exposure on wheat seedlings lead to induction of PCs of different chain lengths $(n=2-4)$. The results that we obtained correspond to previous studies on non-hyperaccumulating species viz., Agropyron repens, Glecoma hederacea, Leonurus marrubiastrum, Lolium perenne, Urtica dioica, Oryza sativa and Zea mays, in which the production of PC2 was predominant over a range of arsenic concentrations [65] [66]. Phytochelatins form complex with metal ions and sequestered them into the vacuole. The high PC2 synthesis in roots of wheat seedlings suggests that the detoxification potential of roots is sufficient to prevent damage in the seedlings.

\section{Conclusion}

In this paper, we conducted concentration-dependent study of sodium arsenate and sodium selenate on growth and thiol metabolism of wheat seedlings. Based on the changes occurring in growth and physiological attributes, wheat provided an ideal system for studying the effect of arsenate toxicity. It can be also concluded that selenium application at low concentration $(10 \mu \mathrm{M})$ reduced the toxic effects caused by arsenic in wheat seedlings by reducing arsenic uptake, suppressing oxidative damage through increase in the level of antioxidants. Thus, 
use of selenium fertilizers in arsenic contaminated fields may have potential to minimize the toxicity caused by arsenic in wheat.

\section{Acknowledgements}

This study was partly supported financially by a Minor Research Grant PSW42/12-13 offered to SG from the University Grants Commission, New Delhi. The authors thank Ms Oindrila Biswas for assistance in generating some of the biochemical assays experimental data.

\section{References}

[1] Banerjee, N. and Giri, A. (2014) Arsenic Induced Health Effects, Genetic Damage and Genetic Variants in the Population Exposed to Arsenic through Drinking Water in West Bengal. Proceedings of Indian National Science Academy, 80, 565-581. https://doi.org/10.16943/ptinsa/2014/v80i3/55130

[2] Zhao, F.J., Ma, J.F., Meharg, A.A. and McGrath, S.P. (2009) Arsenic Uptake and Metabolism in Plants. New Phytologist, 181, 777-794. https://doi.org/10.1111/j.1469-8137.2008.02716.x

[3] Valko, M., Morris, H. and Cronin, M.T. (2005) Metals, Toxicity and Oxidative Stress. Current Medical Chemistry, 12, 1161-1208. https://doi.org/10.2174/0929867053764635

[4] Ghosh, S., Saha, J. and Biswas, A.K. (2013) Interactive Influence of Arsenate and Selenate on Growth and Nitrogen Metabolism in Wheat (Triticum aestivum L.) Seedlings. Acta Physiologiae Plantarum, 35, 1873-1885.

https://doi.org/10.1007/s11738-013-1225-x

[5] Basu, A., Mahata, J., Gupta, S. and Giri, A.K. (2001) Genetic Toxicology of a Paradoxical Human Carcinogen, Arsenic: A Review. Mutation Research, 488, 17141794. https://doi.org/10.1016/S1383-5742(01)00056-4

[6] Hartikainen, H., Xue, T.L. and Piironen, V. (2000) Selenium as an Antioxidant and Prooxidant in Ryegrass. Plant and Soil, 225, 193-200. https://doi.org/10.1023/A:1026512921026

[7] Zeng, H., Uthus, E.O. and Combs Jr., G.F. (2005) Mechanistic Aspects of the Interaction between Selenium and Arsenic-A Review. Journal of Inorganic Biochemistry, 99, 1269-1274. https://doi.org/10.1016/j.jinorgbio.2005.03.006

[8] Srivastava, S., Mishra, S., Tripathi, R.D., Dwivedi, S., Trivedi, P.K. and Tandon, P.K. (2007) Phytochelatins and Antioxidant Systems Respond Differentially during Arsenite and Arsenate Stress in Hydrilla verticillata (L. f.) Royle. Environment Science and Technology, 41, 2930-2936. https://doi.org/10.1021/es062167j

[9] Feng, R., Wei, C., Tua, S. and Sunb, X. (2009) Interactive Effect of Selenium and Arsenic on Their Uptake by Pteris vittata L. under Hydroponic Conditions. Environment and Experimental Botany, 65, 363-368. https://doi.org/10.1016/j.envexpbot.2008.11.013

[10] Pandey, C. and Gupta, M. (2015) Selenium and Auxin Mitigates Arsenic Stress in Rice (Oryza sativa L.) by Combining the Role of Stress Indicators, Modulators and Genotoxicity Assay. Journal of Hazardous Material, 287, 384-391. https://doi.org/10.1016/j.jhazmat.2015.01.044

[11] Pandey, C., Raghuram, B., Sinha, A.K. and Gupta, M. (2015) MiRNA Plays a Role in the Antagonistic Effect of Selenium on Arsenic Stress in Rice Seedlings. Metallomics, 7, 857-866. https://doi.org/10.1039/C5MT00013K 
[12] Kumar, A., Singh, R.P., Singh, P.K., Awasthi, S., Chakrabarty, D., Trivedi, P.K. and Tripathi, R.D. (2014) Selenium Ameliorates Arsenic Induced Oxidative Stress through Modulation of Antioxidant Enzymes and Thiols in Rice (Oryza sativa L.) Ecotoxicology, 23, 1153-1163. https://doi.org/10.1007/s10646-014-1257-z

[13] Ahsan, N., Lee, D., Kim, K., Alam, I., Lee, S., Lee, K., Lee, H. and Lee, B. (2010) Analysis of Arsenic Stress-Induced Differentially Expressed Proteins in Rice Leaves by Two-Dimensional Gel Electrophoresis Coupled with Mass Spectrometry. Chemosphere, 78, 224-231. https://doi.org/10.1016/j.chemosphere.2009.11.004

[14] Grill, E., Mishra, S., Srivastava, S. and Tripathi, R.D. (2007) Role of Phytochelatins in Remediation of Heavy Metals. In: Singh, S.N. and Tripathi, R.D., Eds., Environmental Bioremediation Technologies, Springer, Berlin, 101-146. https://doi.org/10.1007/978-3-540-34793-4_5

[15] Cobbett, C.S. (2000) Phytochelatins and Their Roles in Heavy Metal Detoxification. Plant Physiology, 123, 825-832. https://doi.org/10.1104/pp.123.3.825

[16] Dago, A., Arino, C., Diaz-Cruz, J.M. and Esteban, M. (2014) Analysis of Phytochelatins and Hg-Phytochelatin Complexes in Hordeum vulgare Plants Stressed with $\mathrm{Hg}$ and Cd: HPLC Study with Amperometric Detection. International Journal of Environmental Analytical Chemistry, 94, 668-678. https://doi.org/10.1080/03067319.2013.864649

[17] Hartley-Whitaker, J., Woods, C. and Meharg, A.A. (2002) Is Differential Phytochelatin Related to Decrease Arsenate Influx in Arsenate Tolerant Holcus lanatus? New Phytologist, 155, 219-225. https://doi.org/10.1046/j.1469-8137.2002.00455.x

[18] Schat, H., Llugany, M., Vooijs, R., Hartley-Whitaker, J. and Bleekar, P.M. (2002) The Role of Phytochelatins in Constitutive and Adaptive Heavy Metal Tolerances in Hyperaccumulator and Non-Hyperaccumulator Metallophytes. Journal of Experimental Botany, 53, 2381-2392. https://doi.org/10.1093/jxb/erf107

[19] Zhu, Y.G., Geng, C.N., Tong, Y.P., Smith, S.E. and Smith, F.A. (2006) Phosphate (Pi) and Arsenate Uptake by Two Wheat (Triticum aestivum) Cultivars and Their Doubled Haploid Lines. Annals of Botany, 98, 631-636. https://doi.org/10.1093/aob/mcl139

[20] Barrs, H.D. and Weatherly, P.E. (1962) A Re-Examination of Relative Turgidity for Estimating Water Deficits in Leaves. Australian Journal of Biological Sciences, 15, 413-428. https://doi.org/10.1071/BI9620413

[21] Smith, I.H.C. and Benitez, A. (1956) Chlorophylls: Analysis in Plant Materials. In: Paech, K. and Tracey, M.V., Eds., Modern Methods of Plant Analysis, Springer, Berlin, Vol. 4, 142-196.

[22] Olliver, M. (1967) Ascorbic Acid Estimation. In: Sebrell, W.H. and Harris, R.S., Eds., The Vitamins VI, Academic Press, New York, 338.

[23] Nakano, Y. and Asada, K. (1981) Hydrogen Peroxide Is Scavenged by AscorbateSpecific Peroxidase in Spinach Chloroplasts. Plant Cell Physiology, 22, 867-880.

[24] Mukherjee, S.P. and Chaudhuri, M.A. (1983) Implications of Water Stress-Induced Changes in the Levels of Endogenous Ascorbic acid and Hydrogen Peroxide in Vigna Seedlings. Physiologia Plantarum, 58, 166-170. https://doi.org/10.1111/j.1399-3054.1983.tb04162.x

[25] Backer, H., Frank, O., De Angells, B. and Feingold, S. (1980) Plasma Tocopherol in Man at Various Times after Ingesting Free or Ocetylaned Tocopherol. Nutrition Reports International, 21, 531-536.

[26] Sedlak, J. and Lindsay, R.H. (1968) Estimation of Total, Protein-Bound, and Non Protein Sulfhydryl Groups in Tissue by Ellman's Reagent. Analytical Biochemistry, 
25, 192-208. https://doi.org/10.1016/0003-2697(68)90092-4

[27] Smith, I.K. and Vierheller, T.L. and Thorne, C.A. (1988) Assay of Glutathione Reductase in Crude Tissue Homogenates Using 5, 5-Dithiobis (2-Nitrobenzoic Acid). Analytical Biochemistry, 175, 408-413. https://doi.org/10.1016/0003-2697(88)90564-7

[28] Ranieri, A., Castagna, A., Lorenzini, G. and Soldatini, G.F. (1997) Changes in Thylakoid Protein Patterns and Antioxidant Levels in Two Wheat Cultivars with Different Sensitivity to Sulphur Dioxide. Environmental and Experimental Botany, 37, 125-135. https://doi.org/10.1016/S0098-8472(96)01040-4

[29] Ando, K., Honma, M., Chiba, S., Tahara, S. and Mizutani, J.K. (1988) Glutathione Transferase from Mucor javanicus. Agricultural and Biological Chemistry, 52, 135 139. https://doi.org/10.1271/bbb1961.52.135

[30] Sneller, E.F.C., Van-Heerwaarden, L.M., Schat, H. and Verkleij, J.A.C (2000) Toxicity, Metal Uptake, and Accumulation of Phytochelatins in Silene vulgaris Exposed to Mixtures of Cadmium and Arsenate. Environmental Toxicology and Chemistry, 19, 2982-2986. https://doi.org/10.1002/etc.5620191219

[31] Lowry, O.H., Rosebrough, N.J., Farr, A.L. and Randall, R.J. (1951) Protein Measurement with the Folin Phenol Reagent. Journal of Biological Chemistry, 193, 265 275.

[32] Hu, Y., Duan, G.L., Huang, Y.Z., Liu, Y.X. and Sun, G.X. (2014) Interactive Effects of Different Inorganic As and Se Species on Their Uptake and Translocation by Rice (Oryza sativa L.) Seedlings. Environmental Science and Pollution Research, 21, 3955-3962. https://doi.org/10.1007/s11356-013-2321-6

[33] Abedin, M.J., Feldmann, J. and Meharg, A.A. (2002) Uptake Kinetics of Arsenic Species in Rice Plants. Plant Physiology, 128, 1120-1128.

https://doi.org/10.1104/pp.010733

[34] Bondada, B.R., Tu, S. and Ma, L.Q. (2004) Absorption of Foliar-Applied Arsenic by the Arsenic Hyperaccumulating Fern (Pteris vittata L.). Science of the Total Environment, 332, 61-70. https://doi.org/10.1016/j.scitotenv.2004.05.001

[35] Kapustka, L.A., Lipton, J., Galbraith, H., Cacela, D., and Lejeune, K. (1995) Metallic and Arsenic Impacts to Soils, Vegetation Communities and Wildlife Habitat in Southwest Montana Uplands Contained by Smelter Emissions: II. Laboratory Phytotoxicity Studies. Environmental Toxicology and Chemistry, 14, 1905-1912. https://doi.org/10.1002/etc.5620141112

[36] Hartley-Whitaker, J., Ainsworth, G. and Meharg, A. (2001) Copper and Arsenic Induced Oxidative Stress in Holcus lanatus L. Cloned with Differential Sensitivity. Plant Cell and Environment, 24, 713-722. https://doi.org/10.1046/j.0016-8025.2001.00721.x

[37] Abedin, M.J. and Meharg, A.A. (2002) Relative Toxicity of Arsenite and Arsenate on Germination and Early Seedling Growth of Rice (Oryza sativa L.). Plant and Soil, 243, 57-66. https://doi.org/10.1023/A:1019918100451

[38] Carbonell-Barrachina, A.A., Burlo-Carbonell, F. and Mataix-Beneyto, J. (1995) Arsenic Uptake, Distribution, and Accumulation in Tomato Plants: Effect of Arsenic on Plant Growth and Yield. Journal of Plant Nutrition, 18, 1237-1250. https://doi.org/10.1080/01904169509364975

[39] Mehlhorn, H. (1990) Ethylene-Promoted Ascorbate Peroxidase Activity Protects Plants against Hydrogen Peroxide, Ozone and Paraquat. Plant Cell and Environment, 13, 971-976. https://doi.org/10.1111/j.1365-3040.1990.tb01988.x

[40] Shri, M., Kumar, S., Chakrabarty, D., Trivedi, P.K., Mallick, S., Misra, P., Shukla, D., 
Mishra, S., Srivastava, S., Tripathi, R.D. and Tuli, R. (2009) Effect of Arsenic on Growth, Oxidative Stress, and Antioxidant System in Rice Seedlings. Ecotoxicology and Environmental Safety, 72, 1102-1110.

https://doi.org/10.1016/j.ecoenv.2008.09.022

[41] Singh, H.P., Batish, D.R., Kohali, R.K. and Arora, K. (2007) Arsenic Induced Root Growth Inhibition in Mung Bean (Phaseolus aureus Roxb.) Is Due to Oxidative Stress Resulting from Enhanced Lipid Peroxidation. Plant Growth Regulation, 53, 65-73. https://doi.org/10.1007/s10725-007-9205-Z

[42] Stoeva, N., Berova, M. and Zlatev, Z.L. (2005) Effect of Arsenic on Some Physiological Parameters in Bean Plants. Biologia Plantarum, 49, 293-296. https://doi.org/10.1007/s10535-005-3296-Z

[43] Miteva, E. and Peycheva, S. (1999) Arsenic Accumulation and Effect on Peroxidase Activity in Green Bean and Tomatoes. Bulgarian Journal of Agricultural Sciences, 5, 737-740.

[44] Singh, N., Ma, L.Q., Srivastava, M. and Rathinasabapathi, B. (2006) Metabolic Adaptations to Arsenic-Induced Oxidative Stress in Pteris vittata L and Pteris ensiformis L. Plant Sciences, 170, 274-282. https://doi.org/10.1016/j.plantsci.2005.08.013

[45] Khan, I., Ahmad, A. and Iqbal, M. (2009) Modulation of Antioxidant Defense System for Arsenic Detoxification in Indian Mustard. Ecotoxicology and Environmental Safety, 72, 626-634. https://doi.org/10.1016/j.ecoenv.2007.11.016

[46] Bodannes, R.S. and Chan, P.C. (1979) Ascorbic-Acid as a Scavenger of Singlet Oxygen. FEBS Letters, 105, 195-196. https://doi.org/10.1016/0014-5793(79)80609-2

[47] Czech, V., Czovek, P., Fodor, J., Boka, K., Fodor, F. and Cseh, E. (2008) Investigation of Arsenate Phytotoxicity in Cucumber Plants. Acta Biologica Szegediensis, 52, 79-80.

[48] Flora, S.J.S. (2007) Nutritional Components Modify Metal Absorption, Toxic Response and Chelation Therapy. Journal of Nutritional and Environmental Medicine, 12, 53-67. https://doi.org/10.1080/13590840220123361

[49] Flora, S.J.S., Bhadauria, S., Kannan, G.M. and Singh, N. (2002) Arsenic Induced Oxidative Stress and the Role of Antioxidant Supplementation during Chelation: A Review. Journal of Environmental Biology, 28, 333-347.

[50] Halliwell, B. (1994) Free Radicals and Antioxidants: A Personal View. Nutrition Reviews, 52, 253-265. https://doi.org/10.1111/j.1753-4887.1994.tb01453.x

[51] Bueter, G.R. (1993) The Pecking Order of Free Radicals and Antioxidants: Lipid Peroxidation, $\alpha$-Tocopherol and Ascorbate. Archives Biochemistry Biophysics, 300, 535-543. https://doi.org/10.1006/abbi.1993.1074

[52] Welch, A.H., Helsel, D.R., Focazio, M.J. and Watkins, S.A. (1999) Arsenic in Ground Water Supplies of the United States. In: Chappell, W.R., Abernathy, C.O. and Calderon, R.L., Eds., Arsenic Exposure and Health Effects References, Elsevier, Oxford, 9-17. https://doi.org/10.1016/b978-008043648-7/50004-2

[53] Chang, C.J. and Kao, C.H. (1997) Paraquat Toxicity Is Reduced by Polyamines in Rice Leaves. Plant Growth Regulation, 22, 163-168. https://doi.org/10.1023/A:1005890312557

[54] Mullineaux, P. and Rausch, T. (2005) Glutathione, Photosynthesis and the Redox Regulation of Stress-Responsive Gene Expression. Photosynthesis Research, 86, 459-474. https://doi.org/10.1007/s11120-005-8811-8

[55] Jocelyn, P.C. (1972) Biochemistry of the SH Group: The Occurrence, Chemical Properties, Metabolism and Biological Function of Thiols and Disulphides. Aca- 
demic Press, London.

[56] Ellis, D.R., Gumaelius, L., Indriolo, E., Pickring, I.J., Banks, J.A. and Salt, D.E. (2006) A Novel Arsenate Reductase from the Arsenic Hyperaccumulating Pteris vittata. Plant Physiology, 141, 1544-1554. https://doi.org/10.1104/pp.106.084079

[57] Gratao, P.L., Polle, A., Lea, P.J. and Azevedo, R.A. (2005) Making the Life of Heavy Metal-Stressed Plants a Little Easier. Functional Plant Biology, 32, 481-494. https://doi.org/10.1071/FP05016

[58] Hasanuzzaman, M. and Fujita, M. (2013) Exogenous Sodium Nitroprusside Alleviates Arsenic-Induced Oxidative Stress in Wheat (Triticum aestivum L.) Seedlings by Enhancing Antioxidant Defense and Glyoxalase System. Ecotoxicology, 22, 584-596. https://doi.org/10.1007/s10646-013-1050-4

[59] Hossain, M.A., Hasanuzzaman, M. and Fujita, M. (2010) Up-Regulation of Antioxidant and Glyoxalase Systems by Exogenous Glycinebetaine and Proline in Mung Bean Confer Tolerance to Cadmium Stress. Physiology and Molecular Biology of Plants, 16, 259-272. https://doi.org/10.1007/s12298-010-0028-4

[60] Moons, A. (2003) Osgstu3 and Osgstu4, Encoding Tau Class Glutathione $S$ Transferases, Are Heavy Metal- and Hypoxic Stress-Induced and Differentially SALT Stress-Responsive in Rice Roots. FEBS Letters, 553, 427-432. https://doi.org/10.1016/S0014-5793(03)01077-9

[61] Norton, G.J., Lou-Hing, D.E., Meharg, A.A. and Price, A.H. (2008) Rice-Arsenate Interactions in Hydroponics: Whole Genome Transcriptional Analysis. Journal of Experimental Botany, 59, 2267-2276. https://doi.org/10.1093/jxb/ern097

[62] Chakrabarty, D., Trivedi, P.K., Misra, P., Tiwari, M., Shri, M., Shukla, D., Kumar, S., Rai, A., Pandey, A., Nigam, D., Tripathi, R.D. and Tuli, R. (2009) Comparative Transcriptome Analysis of Arsenate and Arsenite Stresses in Rice Seedlings. Chemosphere, 74, 688-702. https://doi.org/10.1016/j.chemosphere.2008.09.082

[63] Mylona, P.V., Polidoros, A.N. and Scandalios, J.G. (1998) Modulation of Antioxidant Responses by Arsenic in Maize. Free Radical Biology and Medicine, 25, 576-585. https://doi.org/10.1016/S0891-5849(98)00090-2

[64] Zhang, J. and Kirkham, M.B. (1996) Enzymatic Responses of the Ascorbate-Glutathione Cycle to Drought in Sorghum and Sunflower Plants. Plant Sciences, 113, 139-147. https://doi.org/10.1016/0168-9452(95)04295-4

[65] Schulz, H., Hartling, S. and Tanneberg, H. (2008) The Identification and Quantification of Arsenic-Induced Phytochelatins-Comparison between Plants with Varying As Sensitivities. Plant and Soil, 303, 275-287. https://doi.org/10.1007/s11104-007-9507-y

[66] Mishra, S., Jha, A.B. and Dubey, R.S. (2011) Arsenite Treatment Induces Oxidative Stress, Upregulates Antioxidant System, and Causes Phytochelatin Synthesis in Rice Seedlings. Protoplasma, 248, 565-577. https://doi.org/10.1007/s00709-010-0210-0 


\section{Abbreviations}

ACN, Acetonitrile;

AOX, Ascorbic acid oxidase;

APX, Ascorbate peroxidase;

As, Arsenic;

CDNB, 1-Chloro-2,4-dinitrobenzene;

DCPIP, 2,6-dichlorophenol indophenols;

DHAR, dehydroascorbate reductase,

DTNB, 5,5-Dithiobis-2-nitrobenzoic acid;

DTPA, Diethylene triamine penta acetic acid;

DW: Dry weight;

EDTA, Ethylene diamine tetra acetic acid;

FW, Fresh weight;

GSH, Glutathione reduced;

GSSG, Glutathione oxidized;

GPx, Glutathione peroxidase;

GR, Glutathione reductase,

GST, Glutathione-S-transferase,

$\mathrm{H}_{2} \mathrm{O}_{2}$, Hydrogn peroxide;

HEPPS, 4-(2-Hydroxyethyl)-piperazine-1-propanesulfonic acid;

OD, Optical density;

PCs, Phytochelatins;

PFD, Photon flux density;

PVP, Polyvinyl pyrollidone;

ROS, Reactive oxygen species;

Se, Selenium;

SOD, Superoxide dismutase;

TCA, Trichloroacetic acid;

TFA, Trifluoroacetic acid.

\section{Scientific Research Publishing}

Submit or recommend next manuscript to SCIRP and we will provide best service for you:

Accepting pre-submission inquiries through Email, Facebook, LinkedIn, Twitter, etc. A wide selection of journals (inclusive of 9 subjects, more than 200 journals)

Providing 24-hour high-quality service

User-friendly online submission system

Fair and swift peer-review system

Efficient typesetting and proofreading procedure

Display of the result of downloads and visits, as well as the number of cited articles

Maximum dissemination of your research work

Submit your manuscript at: http://papersubmission.scirp.org/

Or contact ajps@scirp.org 